\title{
TEMELJNI TERMINI V GEOGRAFIJI NARAVNIH NESREČ
}

\author{
dr. Karel Natek
}

Oddelek za geografijo, Filozofska fakulteta Univerze v Ljubljani

Aškerčeva 2, SI-I000 Ljubljana

e-mail: karel.natek@guest.arnes.si

Izvirni znanstveni članek

COBISS 1.01

\section{Izvleček}

Prispevek obravnava osnovne strokovne termine v geografiji naravnih nesreč, s katerimi ne samo poimenujemo pojave, ampak vključujejo tudi teoretske in metodološke temelje stroke. Njihovi pomeni so obravnavani z vidika geografije, ki opredeljuje naravne nesreče kot sestavni del pokrajine in iz tega naj bi izhajal tudi geografski pomen teh izrazov. Poenotenje v okviru geografije je še pomembnejše zaradi interdisciplinarnega preučevanja naravnih nesreč, saj obstajajo precejšnje razlike med izrazjem sodelujočih strok.

Ključne besede: geografija, naravne nesreče, nevarnost, ogroženost, tveganje, ranljivost, prilagodljivost, prožnost

\section{BASIC TERMS IN GEOGRAPHY OF NATURAL HAZARDS}

\begin{abstract}
The paper addresses the basic technical terms in the geography of natural disasters, which not only describe the phenomena, but also include its theoretical and methodological foundations. The meanings of these terms are discussed from the viewpoint of geography, which considers natural disasters as an integral part of the environment/ landscape/space. Unification in the context of geography is even more important because of the interdisciplinary approach to natural disasters and significant differences between the terminology of the participating sciences.
\end{abstract}

Key words: geography, natural disasters, hazard, threat, risk, vulnerability, adaptation, resilience 


\section{UVOD}

Celotna zgodovina Zemlje je zaporedje neštetih naravnih dogodkov različne intenzitete, ki se odvijajo po lastnih zakonitostih, neodvisno od človekove prisotnosti ali njegovega subjektivnega zaznavanja. Frekvenčna razporeditev teh pojavov je bolj ali manj normalna: večina dogodkov je nekje v povprečju, le redki dogodki po magnitudi ali drugih značilnostih izrazito izstopajo od ostalih. Že ta razporeditev je z vidika narave povsem nerelevantna, saj je subjektivna, rezultat antropocentričnega pogleda na naravo. Povsem objektivna presoja naravnih dogodkov, ki za nas pomenijo določeno nevarnost (naravne nesreče), je torej že na načelnem nivoju težavna in iz tega izhaja tudi nemoč objektivne opredelitve prvega temeljnega pojma $\mathrm{v}$ geografiji naravnih nesreč: kaj je sploh naravna nesreča?

Natančne opredelitve pojmov so ključnega pomena v znanosti, še zlasti na tako interdisciplinarnih področjih kot je preučevanje naravnih nesreč (Đurović, Mikoš, 2006, 152). Tu se neposredno srečujejo ljudje iz različnih znanstvenih ved, vsak opremljen $z$ metodološkim in terminološkim instrumentarijem svoje stroke. To še posebej velja za temeljne termine, saj niso zgolj imena konkretnih pojavov, temveč so v njih in njihovi uporabi zaobseženi tudi teoretski in metodološki temelji stroke. Pri preučevanju naravnih nesreč so takšni pojmi npr. naravna nesreča, nevarnost, tveganje, ogroženost, ranljivost, ki jih želim podrobneje opredeliti z vidika geografske stroke.

Čeprav je bilo v preteklosti že marsikaj storjenega na področju geografske terminologije, teh izrazov ne uporabljamo vsi v enakem pomenu niti v naši stroki. Še večje so razlike $\mathrm{v}$ pomenu teh izrazov med strokami, ki se prav tako ukvarjajo z naravnimi nesrečami. Njihovo uporabo še dodatno zaplete dejstvo, da se ti izrazi uporabljajo tudi v vsakdanjem, pogovornem jeziku (Đurović, Mikoš, 2006, 152), le da tam njihov eksaktni pomen ni tako zelo pomemben kot $\mathrm{v}$ znanstvenem jeziku.

\section{NEZGODA - NESREČA - KATASTROFA - KATAKLIZMA}

V slovenskem jeziku imamo štiri izraze, ki jih pogosto uporabljamo za dogodke z nezaželjenimi učinki, od najmilejših do nepredstavljivo silovitih: nezgoda - nesreča katastrofa - kataklizma.

Slovar slovenskega knjižnega jezika (v nadaljevanju SSKJ) skorajda ne razlikuje med izrazoma nesreča in nezgoda: Nesreča je »1. stanje, ki povzroča duševne bolečine; 2 . dogodek, pri katerem je človek poškodovan ali mrtev // dogodek, ki človeka zelo prizadene, navadno materialno; 3. dogodek, ki povzroča človeku zadrego, neprijeten občutek; nezgoda«, nezgoda pa je »1. dogodek, pri katerem je človek poškodovan; 2. dogodek, ki človeka zelo prizadene, navadno materialno; nesreča; 3. ekspr. dogodek, ki povzroča človeku zadrego, neprijeten občutek«. Razlika v splošni rabi je morda v tem, da je pri nesreči lahko človek »poškodovan ali mrtev«, pri nezgodi pa le »poškodovan«. Pri razjasnjevanju nam ne pomaga dosti niti etimološki slovar, saj sta v njem oba pojma obravnavana le posredno: nezgoda je z etimološkega vidika, kadar se nekaj ni zgodilo, nesreča pa je zla sreča (Snoj, 1997).

V splošni rabi se izraz nesreča uporablja sicer veliko pogosteje (Nova beseda: 10.371 zadetkov) kot nezgoda (411 zadetkov), vendar pa se v medijih pojavljajo celo prometne 
nezgode s smrtnimi žrtvami. To seveda ni niti pravilno niti etično, saj je takšen dogodek huda nesreča oziroma katastrofa za prizadeto družino in ne nezgoda kot zgolj neprijeten dogodek, zaradi katerega nas še nekaj dni boli prst na levi roki. Izraz nezgoda bi bilo po mojem mnenju ustrezneje uporabljati za manjše dogodke brez hujših posledic, ali celo v etimološko prvotnem pomenu (nekaj bi se lahko zgodilo, pa se na srečo ni), kot npr.: »V Rušah se je zaradi hudega naliva zgodila celo železniška nezgoda. Nekaj minut pred 22. uro so tire v bližini Falske pečine zasuli blato, kamenje in stara drevesa, kmalu zatem pa je tja pripeljal motorni potniški vlak.« (Delo, 30. 7. 2003; cv: Nova beseda, 2011).

Izraz nezgoda torej v strokovnem pisanju ne pride v poštev, saj so učinki nezgod preneznatni, čeprav se beseda občasno pojavlja kot nadomestek za izraz dogodek, npr. pri Gamsu $(1983,12)$ : »Med naravne nesreče, ki jih bomo obravnavali na današnjem posvetu, smo uvrstili tudi gozdne požare. To smo storili v skladu z naziranjem, da štejemo med naravne nesreče vse nezgode, ki se lahko javljajo tudi brez človekovega vpliva.«

V Zakonu o varstvu pred naravnimi in drugimi nesrečami (2006) se izraz nesreča uporablja v precej zoženem pomenu za »dogodek ali vrsto dogodkov, povzročenih po nenadzorovanih naravnih in drugih silah, ki prizadenejo oziroma ogrozijo življenje ali zdravje ljudi, živali ter premoženje, povzročijo škodo na kulturni dediščini in okolju v takem obsegu, da je za njihov nadzor in obvladovanje potrebno uporabiti posebne ukrepe, sile in sredstva, ker ukrepi rednih dejavnosti, sile in sredstva ne zadostujejo.« Po dikciji zakona torej dogodek postane nesreča šele, ko so njegove posledice za ljudi, njihovo premoženje, živali, kulturno dediščino (naravna dediščina ni vključena - prim. skalni podor, ki je junija 2008 uničil slap Čedca nad Jezerskim; Frantar, Robič, 2009) ali okolje tolikšne, da redni ukrepi ne zadoščajo, ampak je treba uporabiti »posebne ukrepe, sile in sredstva«.

Slika 1: Velik skalni podor je junija 2008 uničil slap Čedca-dotlej najvišji slap v Sloveniji (foto: K. Natek; 22. 6. 2008)

Figure 1: Large rockslide in June 2008 destroyed the waterfall Čedca-the highest waterfall in Slovenia (photo: K. Natek; 22. 6. 2008)

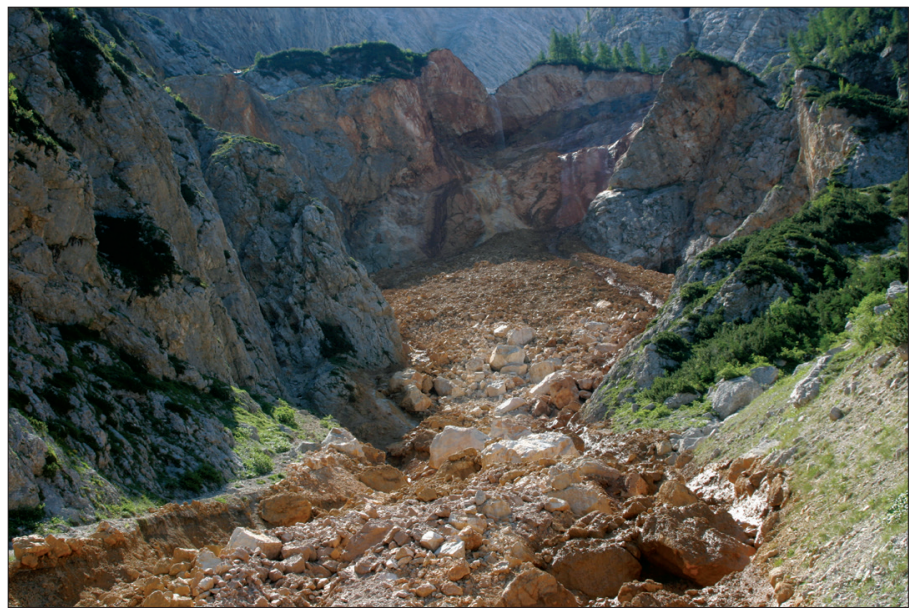


Takšen pomen odstopa od rabe v vsakdanjem jeziku, kjer uporabljamo besedo nesre$\check{c} a$ tudi za opisovanje povsem osebnega razmerja med določenim dogodkom in posameznikom, ki doživi njegove negativne posledice, ne glede na velikost dogodka. Nesreča na avtocesti je že, kadar nekdo z avtomobilom podrsa po zaščitni ograji in ga poškoduje, pri delovni nesreči si delavec $\mathrm{v}$ tovarni poškoduje prst, pa niso potrebni nikakršni »posebni ukrepi, sile in sredstva«. Tudi dikcija "po nenadzorovanih naravnih in drugih silah « je neustrezna in zavajajoča, saj vsebuje trditev, da so te sile sicer pod nadzorom, da jih torej obvladujemo, kar seveda ne velja niti za 'antropogene' sile, še manj za naravne, ki jih ne bomo nikoli sposobni nadzorovati.

Slika 2: Neurje s točo je 23. 7. 2005 povsem uničilo vinograde in druge kmetijske kulture v širši okolici Virštanja (foto: K. Natek; 24. 7. 2005)

Figure 2: Hailstorm on July 23, 2005, completely destroyed the vineyards and other crops in Virštanj and surroundings (photo: K. Natek; 24. 7. 2005)

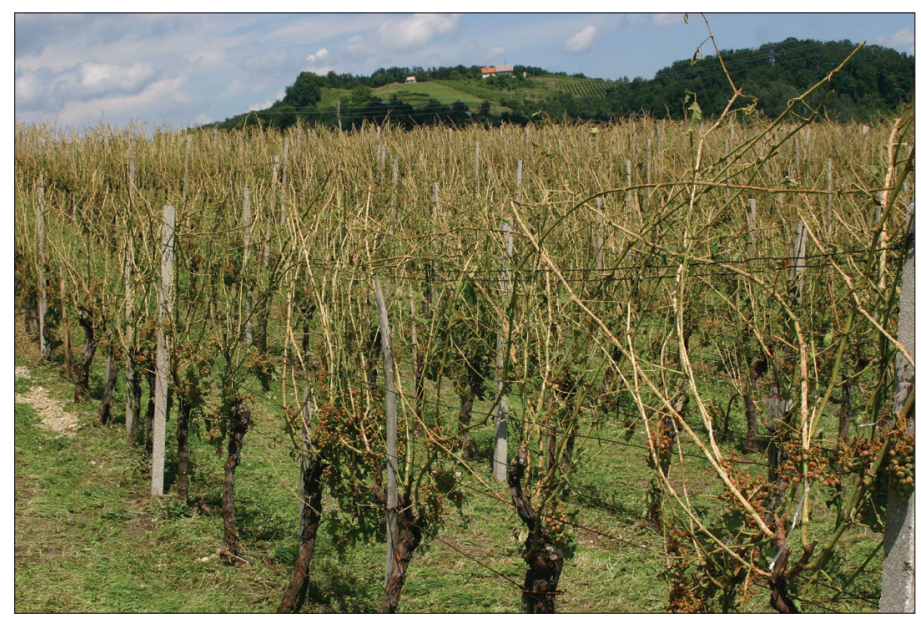

Za dogodke z zelo hudimi in obsežnimi posledicami se pogosto uporablja izraz $k a$ tastrofa. Stopnjevanje v primerjavi z nesrečo je jasno opredeljeno v SSKJ: »1. dogodek v naravi, ki povzroči veliko razdejanje, uničenje / naravna katastrofa; 2. zelo hud, neprijeten dogodek z usodnimi posledicami, nesreča; 3. uničenje, propad«. Dodan je še poseben geološki pomen: »dogodek v naravi, ki povzroči velike spremembe na zemeljski površini ali v vesolju«.

Pomen izraza katastrofa je natančneje opredeljen v Geografskem terminološkem slovarju (2005, 167): »1. izreden dogodek, huda nesreča, ki povzroči izjemno veliko razdejanje in številne žrtve; 2. težko predvidljivo dogajanje v naravi, npr. poplave, potresi, nastalo tudi zaradi človekovega neustreznega poseganja v okolje, ki z veliko močjo v kratkem času zelo spremeni naravno in antropogeno okolje ter ogrozi zdravje, življenje velikega števila ljudi, drugih organizmov.« 
S prvim pomenom se zlahka strinjamo, pri drugem je potreben nekoliko globlji razmislek: Ali so katastrofe res težko predvidljive (verjetnost potresov, poplav, tropskih viharjev idr. je možno predvideti na osnovi pogostnosti pojavljanja v preteklosti, ne moremo pa napovedati točnega kraja in časa) in, ali to res vključuje tudi 'dogajanje v naravi', ki je nastalo zaradi človekovega neustreznega poseganja v okolje? Ta formulacija je prišla v definicijo verjetno pod vplivom razprav o globalnem spreminjanju podnebja na Zemlji zaradi nezmernega trošenja fosilnih goriv, čeprav so učinki teh sprememb na pojavljanje vremenskih ujm le zelo verjetni, težko pa je dokazati njihovo večjo pogostnost in silovitost. Vključuje pa ta definicija še eno dilemo, ki jo v svojem antropocentričnem pogledu na naravne nesreče pogosto spregledamo: ali so pomembne samo hude posledice nekega naravnega dogodka za človeka/družbo ali tudi za druge organizme? Bi bil pogin stotisočev cesarskih pingvinov na Antarktiki samo naravni dogodek ali naravna nesreča?

Izraz kataklizma prinaša še nadaljnje stopnjevanje negativnih učinkov. Po SSKJ je to »dogodek v naravi, ki povzroči velike spremembe na zemeljski površini ali v vesolju: uničenje vsega živega v strahotni kataklizmi; vesoljska kataklizma«. Iz splošne rabe (Nova beseda; 302 zadetka) je razvidno, da se beseda uporablja tudi za povsem antropogene dogodke (npr. kataklizmi prve in druge svetovne vojne, černobilska kataklizma), oziroma za dogodke, ki so se zgodili pred nastankom človeka (izumrtja večine živih bitij v geološki preteklosti, npr. ob koncu krede zaradi padca velikega meteorita).

S strokovno revijo Ujma, ki je od prve številke leta 1987 objavila desetine prispevkov o naravnih in drugih nesrečah, se je v slovenskem jeziku ponovno obudila raba besede ujma za »dogodek, pojav v naravi, ki povzroči veliko škodo: pokrajino je prizadela ujma; povodenj, suša in druge ujme / vodna, vremenska ujma // dogodek, pojav, ki povzroča veliko trpljenje: lakota, vojska in druge ujme« (SSKJ). V geografiji uporabljamo izraz v ožjem pomenu za »dogodek, pojav v naravi, ki povzroča škodo širšega obsega, nastal zaradi izjemnih vremenskih dogajanj« (Geografski terminološki slovar 1998, 407).

\section{NARAVNA NESREČA}

Radinja $(1983,17)$ je na prvem jugoslovanskem znanstvenem simpoziju o naravnih nesrečah leta 1983 izpostavil, da v geografiji »... z njimi pojmujemo (navadno) nenadne in uničujoče (silovite) naravne pojave, ki bodisi življenjsko, gmotno ali obojno močno prizadenejo prebivalstvo ... Pri vseh teh pojavih gre za zelo neposredno in izrazito, izjemno dinamično razmerje med naravnim okoljem in družbo, pravzaprav za njihovo vrednotenje z družbenega vidika. Prav zato, ker usodno prizadenejo ljudi, njih same ali njihove življenjske osnove, skratka, naravne in družbene elemente pokrajine, jih označujemo za nesreče ali katastrofe ... Že sama oznaka je tipično geografska, saj izraža odnos med naravo in družbo, ko naravne pojave vrednoti (negativno seveda) s stališča človeka, kajti nesreča je izključno sociološka pojmovna kategorija.«

V Geografskem terminološkem slovarju $(2005,238)$ je naravna nesreča definirana kot »nesreča, ki jo povzročijo izjemne naravne okoliščine, npr. potres, zemeljski plaz, podor, poplava, suša, vetrolom, toča, pozeba, žled, snegolom«. Definicija ni najbolj 
posrečena, saj pojem definira s samim sabo (nesreča je nesreča ...), hkrati pa vso 'krivdo' neupravičeno pripiše 'naravnim okoliščinam', čeprav lahko k njihovemu pojavljanju posredno ali neposredno prispeva tudi človek (prim. definicijo besede katastrofa $\mathrm{v}$ istem slovarju). Po drugi strani navedena definicija dobro ločuje med naravno nesrečo kot jasno opredeljenim dogodkom (potres, podor, poplava, itd.) in naravno nevarnostjo kot izjemno (naravno) okoliščino, ki lahko povzroči naravno nesrečo.

Zakon o varstvu pred naravnimi in drugimi nesrečami (2006) pri definiranju pojma naravna nesreča izhaja iz zelo zožene definicije besede nesreča (dogodek tolikšnega obsega, da so potrebni posebni ukrepi, sile in sredstva, saj ukrepi rednih dejavnosti ne zadostujejo) in v definiciji zgolj našteva vrste dogodkov, ki so lahko naravna nesreča, ne glede na njihovo intenziteto, obseg ali pogostnost pojavljanja: »Naravne nesreče so potres, poplava, zemeljski plaz, snežni plaz, visok sneg, močan veter, toča, žled, pozeba, suša, požar v naravnem okolju, množični pojav nalezljive človeške, živalske ali rastlinske bolezni in druge nesreče, ki jih povzročijo naravne sile. Za naravno nesrečo se štejejo tudi neugodne vremenske razmere po predpisih o kmetijstvu in odpravi posledic naravnih nesreč, ki jih povzročijo žled, pozeba, suša, neurje, toča ali živalske in rastlinske bolezni ter rastlinski škodljivci.»

Zemlja je izrazito dinamičen planet, a je potek naravnih procesov s fizikalnega vidika zgolj niz dogodkov v toku časa: v skladu z naravnimi zakonitostmi se dogodki pojavljajo $\mathrm{v}$ sedanjosti in drug za drugim izginjajo $\mathrm{v}$ preteklost. $\mathrm{V}$ tem naravnem dogajanju ne moremo iskati kriterijev za določanje, kateri dogodki so naravna nesreča, saj ta kategorija v objektivni stvarnosti ne obstaja, tam so samo zaporedja dogodkov. Je pa v geografiji zelo pomembno, da dogodke obravnavamo kot sestavne dele pokrajine, temeljnega predmeta geografije kot prizorišča zapletenih odnosov med naravo in družbo. V tem vzročno-posledičnem kontekstu obstajajo (jih obravnavamo) naravne nesreče kot »naravni dogodki, ki jih ljudje občutimo kot grožnjo za naša življenja in/ali imovino in pri katerih je družba ali njen del izpostavljen tolikšni nevarnosti in izgubam ljudi ter imovine, da pride do motenj v delovanju družbe« (Natek, 2011). Iz te definicije izhajajo trije kriteriji, na osnovi katerih lahko dogodek opredelimo kot naravno nesrečo:

- izjemnost dogodka (predvsem po magnitudi in pogostnosti);

- družba (ne zgolj posameznik) občuti dogodek kot grožnjo;

- stopnja nevarnosti in/ali izgube so tolikšne, da družba ne more več normalno delovati in je potrebno uvesti posebne ukrepe.

Po SSKJ je dogodek nekaj, »kar se zgodi«, zgoditi se pa »izraža uresničitev dejanja, dogodka v stvarnosti«. Takšna definicija je nekoliko preohlapna z dveh vidikov: $\mathrm{z}$ vidika pozitivistične znanosti so dogodki (pojavi) samo tisto, kar je moč opazovati (meriti). Že iz tega izhaja podmena, da so tudi $d o g o d k i$, ki jih še ne znamo izmeriti ali jih morda celo ni moč izmeriti. Magnetni vihar, ki ga povzročijo visoko naelektreni delci s Sonca, ko dosežejo Zemljino magnetosfero, so prvič zabeležili šele na začetku 19. st. Naravna nesreča je prvič 'postal' 13. marca 1989, ko se je zaradi njega sesul celoten elektroenergetski sistem v kanadski provinci Québec in v delih na severovzhodu ZDA in je brez električne energije za več kot devet ur ostalo 9 milijonov ljudi (Boteler, Pirjola, Nevanlinna, 1998). 
Naravna nesreča tudi ni nujno dogodek, uresničitev dejanja, dogodka v stvarnosti, lahko je tudi samo neko določeno stanje, celo odstotnost dogodkov (npr. suša zaradi pomanjkanja padavin).

Zaradi izrazite antropocentričnosti pojem naravna nesreča ni najbolj posrečen, vendar imajo podobne težave tudi v drugih jezikih. V angleškem jeziku je natural hazard definiran kot »naravni dogodek (event), ki ga človeštvo (mankind) zazna kot grožnjo (threat) za življenja in imovino« (Whittow, 2000, 241), čeprav pomeni beseda hazard v splošnem jeziku tudi »slučaj; tveganje; nevarnost; igro na slepo srečo« (Grad, Škerlj, Vitorovič, 1998, 397). Zato bi bilo izraz natural hazard ustrezneje prevajati kot naravna nevarnost (prim. Đurović, Mikoš, 2006), za našo naravno nesrečo je v angleškem jeziku ustreznejši izraz natural disaster.

Oxford English Dictionary definira besedo disaster kot »vse, kar se dogodi škodljivega (ruinous) ali kar povzroča stisko (distressing), nenadna ali velika nesreča (misfortune, mishap, misadventure), katastrofa (calamity).« Po istem viru je izraz hazard »tveganje (risk) izgube ali poškodbe; nevarnost (peril, jeopardy)«.

Wisner in sod. $(2004,49)$ definirajo nevarnost (hazard) kot »... naravne dogodke, ki lahko posamično ali v kombinaciji prizadenejo določena območja (obale, pobočja, tektonske prelome, savano, deževni gozd) v določenem času (letni čas, čas dneva, različno dolga povratna doba). Nevarnost ima različne stopnje intenzivnosti in ostrine (severity).« Nesreča (disaster) se pojavi, »ko je večje število ranljivih ljudi izpostavljeno nevarnosti ter utrpi resne poškodbe in/ali tolikšne motnje v njihovem sistemu vsakdanjega življenja, da okrevanje (recovery) ni možno brez zunanje pomoči.« (Wisner in sod., 2004, 50).

V nemškem jeziku uporabljajo izraza Naturgefahr v splošnejšem pomenu in Naturkatastrophe za dogodke večjih razsežnosti, vendar zlasti prvi izraz nima povsem enakega pomena kot naša naravna nesreča. Naturgefahr (dobesedno naravna nevarnost) je »proces, ki ga sprožijo ali spodbudijo značilnosti reliefa, ledu, vode in/ali substrata oziroma prsti in, čeprav poteka po naravnih zakonitostih, ogroža naravno ravnovesje geoekosistemov. Potek procesa in njegov končni učinek lahko škodujejo ljudem, naseljem in gospodarstvu.« (Leser in sod., 1995, 2, 14). Naturkatastrophe (naravna katastrofa) pa je »izjemni naravni dogodek z velikimi posledicami za ljudi, njihova življenja in gospodarstvo.« K definiciji je dodano: »Šele zaradi posledic na ljudi postanejo naravni dogodki katastrofe.« (Geografie, 2007, 355).

Prav ničesar ne pridobimo, če se poskušamo izogniti ne povsem posrečenemu izrazu naravna nesreča, kot npr. Đurović in Mikoš (2006, 152): »Naravni dogodek (geološki, geomorfološki, klimatološki, ... ) je preprosto naravni pojav ali proces oziroma kot navaja White (1974): 'katerikoli dogodek v geofizikalnem sistemu, ki izkazuje relativno visoko varianco', medtem ko je naravna nevarnost potencialno nevarna človeškim življenjem in materialnim dobrinam, ali povedano drugače: 'Naravna nevarnost je objektivno grozeča nesreča zaradi nevarnega procesa $\mathrm{v}$ naravi in povezuje vse poteke in vplive narave, ki so lahko škodljivi za osebe in/ali stvari.' (Kienholz et al., 1998).«

Z geografskega vidika lahko to opredelitev nadgradimo z dvema, za geografijo ključnima dimenzijama tovrstnih dogodkov - s povezanostjo med naravo in družbo ter naravnimi nesrečami kot sestavnim delom pokrajine. S tega vidika je do neke mere umestno ločevati 
med naravnim dogodkom kot nekaj izključno naravnega in naravno nevarnostjo, ki naj bi v naravi prežala na človeka in ogrožala njegovo življenje ter materialne dobrine. Še več, izraza tudi v semantičnem pogledu nista sinonima, saj je nevarnost stanje, možnost, verjetnost, okoliščine, v katerih lahko pride do nesreče, ta pa je konkreten, končni dogodek.

\section{NEVARNOST}

Beseda ima v SSKJ več pomenov, razlikovanje med njimi je pomembno tudi z vidika preučevanja naravnih nesreč:

- lastnost, značilnost nevarnega;

- možnost nesreče, škode ali česa slabega, neprijetnega sploh;

- stanje, nastalo zaradi take možnosti;

- razmere, okoliščine, zaradi katerih lahko pride do nesreče, škode ali česa slabega, neprijetnega sploh.

$\mathrm{V}$ pokrajini kot sklopu naravnih in družbenih procesov, prepletenih z nešteto vzročno-posledičnih povezav, delujejo naravni procesi ne glede na prisotnost človeka, mi smo jim dodali še naravno-antropogene in povsem antropogene procese. Vsi ti procesi in njihove kombinacije $\gg . .$. predstavljajo določene okoliščine oziroma nevarnost (angl. hazard), zaradi katere lahko pride do škode ali nesreče. Nevarnost razumemo kot naravni ali po človeku sproženi dogodek oziroma proces, ki lahko povzroči izgubo. Prisotnost takšnih okoliščin je mogoče ugotoviti z različnimi metodami, včasih lahko nevarnost tudi izmerimo ali celo napovemo, na primer nevarnost 100-letne poplave, potresa ali vulkanskega izbruha.« (Komac, Natek, Zorn, 2008, 37).

Zakon o varstvu pred naravnimi in drugimi nesrečami (2006) uporablja izraz nevarnost nesreče. To »... je verjetnost, da se bo zgodila nesreča in prizadela oziroma ogrozila življenje ali zdravje ljudi in živali ter povzročila uničenje ali škodo na premoženju, kulturni dediščini in okolju.« S tem se je težko strinjati in bom poskušal v nadaljevanju dokazati, da je nevarnost dejanska, stvarna sestavina okolja/pokrajine, verjetnost, da se bo zgodilo nekaj, kar ogroža ter povzroča škodo, pa je ogroženost.

Natančno definiranje pomena besede nevarnost ni enostavno, saj je že v navedenih dveh definicijah nekaj pomembnih pomenskih odtenkov. Še več definicij navajata Đurović in Mikoš $(2006,152)$ iz drugih virov, npr.

- »Nevarnost (hazard) je (naravna ali druga ustrezna) danost za kateri koli neugoden pojav, ki je povezan z mogočo nesrečo in lahko povzroči neugodne učinke. Govorimo o potresni, poplavni, požarni itd. nevarnosti. Nevarnost je verjetnostni pojem in jo opredeljujemo $\mathrm{z}$ verjetnostjo prekoračitve, torej $\mathrm{z}$ vrednostmi med 0 in $1 . \ll$ (Lapajne, 1987, 94);

- „Nevarnost je verjetnost nastopa potencialno nevarnega pojava v določenem časovnem intervalu in na nekem območju. « (Varnes, 1984);

- »Nevarnost je geološko stanje ali pojav, ki se pojavlja v naravi ali ga je povzročil človek, in predstavlja tveganje oziroma je potencialno nevaren za življenja ali lastnino.« (Alexander, 1993); 
- $\quad$ Nevarnost je najopaznejša kot proces, ki se pojavlja v naravi ali ga je sprožil človek, oziroma kot dogodek s potencialom ustvariti izgubo.« (Smith, 2004);

- $\quad$ Nevarnost je stanje, razmere ali potek, iz katerega lahko nastane škoda. Je možnost nastopa nevarnega procesa s povzročitvijo škode.« (Kienholz in sod., 1998).

Vsem definicijam je skupno, da je nevarnost nekaj v pokrajini, kar lahko povzroči neko škodo, vendar se razlikujejo med seboj po tem, kaj je to: dogodek, proces, potek, verjetnost, okoliščine, danost, stanje, razmere, itd. Ali je torej nevarnost ena od objektivnih danosti naravnih pojavov ali procesov, oziroma geografsko gledano, sestavni del pokrajine, ali je to zgolj subjektivna kategorija, specifičen človekov pogled na naravo?

G. White je že pred desetletji zapisal trditev, da »po definiciji, naravne nesreče (angl. natural hazards) ne obstajajo ločeno od človekove prilagoditve. Vedno je vključena človekova pobuda in izbira." (White, 1974, 3). S to trditvijo se ne morem povsem strinjati, vendar je razlog za nestrinjanje zgolj terminološke narave, kar se razkrije iz nadaljnjega Whiteovega razmišljanja: »Poplave ne bi predstavljale nevarnosti (angl. hazard), če jih človek ne bi izzival z naseljevanjem poplavnih ravnic: šele z njihovim prilaščanjem ustvarja možnost škode (angl. damage potential), lahko pa tudi spreminja sam poplavni režim.« (White, 1974, 3). Avtor govori torej o ogroženosti in ne več o nevarnosti, tako da lahko na prvi del zgoraj zastavljenega vprašanja odgovorimo, da je nevarnost objektivna danost, sestavni del narave/pokrajine in šele človek, oziroma družba $v$ ta odnos med naravo in družbo vneseta subjektivni vidik, ki ga lahko imenujemo ogroženost. Precej podobno menita Đurović in Mikoš $(2006,153)$ : »Če taka nevarnost obstaja in je kulturi lahko nevarna le posredno, potem je naravna nevarnost objektivni del nature, ki pa ima v zvezi s potencialom vplivanja na kulturo tudi svojo subjektivno plat. Torej lahko s tega stališča zaključimo, da je nevarnost sama po sebi objektivna, človeška ogroženost pa subjektivna. Tako definirana naravna nevarnost torej obstaja tudi kadar je potencialno nevarna le (!) živalskim življenjem in njihovemu naravnemu okolju, torej je objektivnega značaja in šele družba jo subjektivizira v smislu ogrožanja te iste družbe, neposredno ali posredno.«

Tudi Alexander $(1999,7)$ izpostavlja objektivni vidik izraza nevarnost (angl. hazard) in mu posredno dodaja geografsko vsebino - razmere pred nesrečo lahko razumemo kot stanje v pokrajini, oziroma kot pokrajinsko sestavino: »Nevarnost lahko definiramo kot razmere pred nesrečo, ko obstaja določeno tveganje, prvenstveno zato, ker so se ljudje sami spravili v stanje ranljivosti (angl. vulnerability).«

Pojasnimo si to na primeru snežnih plazov v dolini Trente v Zgornjem Posočju! Ti so pomemben sestavni del te pokrajine, saj so fizičnogeografske razmere/okoliščine zanje naravnost idealne: dolga strma pobočja od vršnih grebenov do dolinskega dna, obilne snežne padavine, skromna poraščenost najstrmejših delov pobočij, v pobočja vrezani erozijski jarki in grape kot poti potencialnih snežnih plazov itd. V tej pokrajini so snežni plazovi obstajali, še preden se je vanjo naselil prvi človek in pojavljajo se tudi zdaj, vendar so se ljudje sčasoma tem okoliščinam/danostim prilagodili in zmorejo živeti z njimi. Naravne razmere namreč niso takšne, da bi se lahko snežni plazovi pojavljali kjer koli, ampak samo na nekaterih mestih in tam obstaja nevarnost, da v primernih okoliščinah s pobočja prihrumi snežni plaz. Takrat je na tistem mestu, območju, ki ga je moč na 
osnovi izkušenj s preteklimi snežnimi plazovi ali/in z modeliranjem dokaj natančno omejiti, zares nevarno, vendar ne $\mathrm{v}$ celotni dolini. Ta nevarnost tudi ni vedno prisotna, ampak samo v zimski polovici leta, ko na območju, 'primernem' za nastanek snežnega plazu, obstajajo objektivne možnosti za njegov nastanek, torej dovolj velika količina ustreznega snega. Torej, nevarnost snežnega plazu na tistem mestu in v določenem času ni »... objektivno grozeča nesreča zaradi nevarnega procesa v naravi ...« (Đurović, Mikoš, 2006, 152), saj niti ni nujno, da do nevarnega procesa (sproženja snežnega plazu) sploh pride, ampak gre samo za prisotnost okoliščin (Komac, Natek, Zorn, 2008, 37), v katerih lahko pride do takšnega dogodka, procesa, poteka.

Če bi si nekdo na takšnem 'nevarnem' kraju nespametno postavil stanovanjsko ali počitniško hišo, nevarnost snežnih plazov v Trenti ne bi bila nič večja, bi pa ljudje s takšnim ravnanjem $\mathrm{v}$ pokrajino vnesli novo pokrajinsko sestavino: ogroženost zaradi snežnih plazov. Ker so snežni plazovi v Trenti razmeroma pogost pojav, se domačini zavedajo te nevarnosti, oziroma poznajo nevarna območja, zato so svoje zavedanje nevarnosti $\mathrm{v}$ preteklosti upoštevali pri lociranju svojih bivališč in jo s tem vgradili v pokrajino (Natek, 2002, 65). Težave se pojavijo, kadar pridejo v pokrajino ljudje brez teh izkušenj in poznavanja naravnih danosti in si zgradijo bivališča na nevarnih območjih, pri gradnji prometnic, ki jih je pogosto potrebno speljati prek izrazito nevarnih območij (ogroženost je možno učinkovito zmanjšati z varovalnimi napravami ali v skrajnem primeru s prepovedjo uporabe prometne poti za čas nevarnosti), in pri občasnih obiskovalcih, ki se na nevarnih območjih zadržujejo v času nevarnosti iz rekreativnih in drugih nagibov.

Slika 3: Snežni plazovi in skalni podori z dolgih in strmih pobočij so pogost pojav v dolini Trente (foto: K. Natek)

Figure 3: Avalanches and rockfalls from long and steep slopes are a common occurrence in the Trenta Valley (photo: K. Natek)

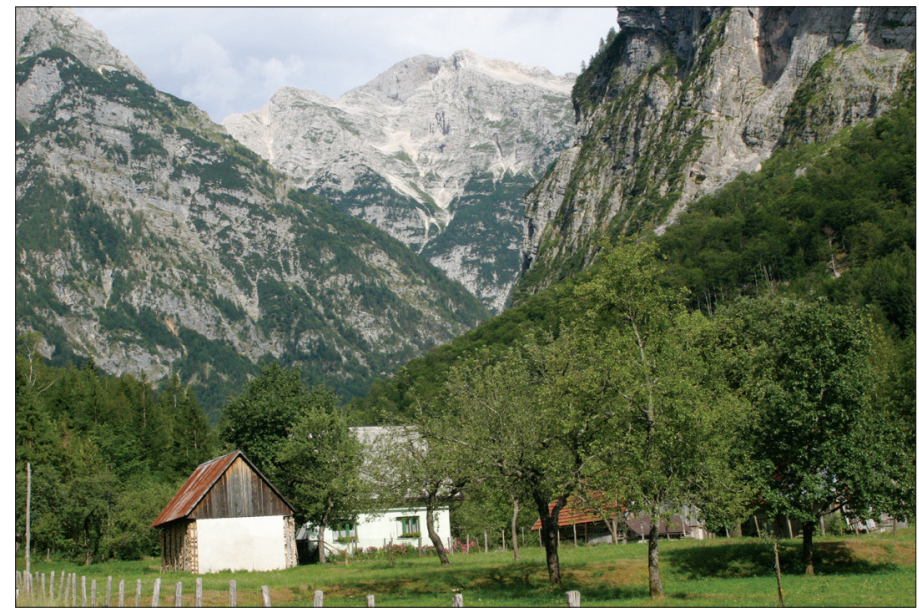


Ker pa »... se zgodi, da ob izjemnih snežnih padavinah nastanejo plazovi tudi izven nevarnih območij ali pa postanejo izjemno veliki in povzročijo hude katastrofe ...« (Natek, 2002, 65), kar se je v Zgornjem Posočju zgodilo npr. februarja 1952 (Gams, 1955), ne moremo nevarnosti snežnih plazov omejiti zgolj na nevarna območja, ampak jih z ustrezno stopnjo verjetnosti ekstrapoliramo na celotno pokrajino. Takšna so npr. tudi redna opozorila Urada za meteorologijo o nevarnosti snežnih plazov, npr. »Zaradi novozapadlega snega je v visokogorju Julijskih Alp velika nevarnost proženja snežnih plazov.« Opozorila pravilno govorijo zgolj o nevarnosti, torej o obstoju okoliščin, v kakršnih je z ustrezno stopnjo verjetnosti možno pričakovati proženje snežnih plazov, in ne govorijo o ogroženosti. Ta se pojavi šele, ko se v takšnih nevarnih okoliščinah ljudje (kljub opozorilom) odpravijo v gore in se s tem izpostavijo visoki stopnji ogroženosti.

Razlika med pojmoma nevarnost in ogroženost je jasno opredeljena tudi v evropski direktivi o oceni in obvladovanju poplavne ogroženosti, ki zahteva od držav članic EU pripravo kart poplavne nevarnosti in poplavne ogroženosti ter načrte za obvladovanje poplavne ogroženosti (Direktiva, 2007). Po tej direktivi »karte poplavne nevarnosti zajemajo geografska območja, na katerih lahko pride do naslednjih vrst poplav: (a) poplav z majhno verjetnostjo oziroma poplav, kot posledice izrednih dogodkov; (b) poplav s srednjo verjetnostjo (verjetna povratna doba 100 let); (c) poplav z veliko verjetnostjo, kjer je to primerno.« (Direktiva, 2007, 30). Z drugimi besedami, karta poplavne nevarnosti je karta poplavnih območij, na katerih so prikazane tri stopnje pogostnosti oziroma verjetnosti pojavljanja poplav na osnovi treh, vnaprej določenih kazalcev (obseg poplav, globina ali višina gladine poplavne vode in po potrebi hitrost toka ali pretok vode). Karte poplavne ogroženosti pa »prikazujejo morebitne škodljive posledice, povezane z različnimi vrstami poplav, vključno z informacijami o mogočih virih onesnaževanja okolja zaradi poplav. Pri tem bi morale države članice oceniti dejavnosti, zaradi katerih se povečuje poplavna ogroženost.« (Direktiva, 2007, 28).

\section{OGROŽENOST}

Z izrazom ogroženost vstopa v odnos med naravnim dogajanjem ter človekom oziroma družbo človeški, družbenogeografski vidik, vendar se s to 'antropogeno' razsežnostjo pojma ne strinjajo vsi. Eni namreč menijo, da je ogroženost v naravi/pokrajini (ta seveda vključuje tudi antropogene sestavine, kot npr. poselitev, rabo tal, infrastrukturo) prisotno stanje, drugi, da nastopi šele, ko naravni dogodki neposredno ogrozijo ljudi. Po SSKJ je beseda grožnja res izrazito vezana na človeka in v naravi naj ne bi obstajala (»obljuba, napoved komu česa neprijetnega, hudega«), ampak po istem viru je ogroženost tudi »lastnost, stanje ogroženega«. Le za odtenek drugačna je definicija angleškega izraza za ogroženost (risk) v Oxford English Dictionary: »(Izpostavljenost) možnost izgube, poškodbe in druge sovražne ali nezaželjene okoliščine; verjetnost ali situacija, ki vsebuje takšno možnost.«

Geografski terminološki slovar $(2005,261)$ pojma ogroženost ne definira, pač pa ogroženost okolja (»verjetna nevarnost, da se zaradi škodljivega delovanja človeka kakovost določenega okolja poslabša in se zveča njegova prizadetost«) ter ogroženost ozemlja 
(»izpostavljenost določenega ozemlja naravnim in drugim nesrečam«). Mojemu razumevanju ogroženosti zaradi naravnih nesreč je drugi pomen bližji, vendar se oba navedena pomena precej razlikujeta (v prvi definiciji je ogroženost verjetna nevarnost, $\mathrm{v}$ drugi izpostavljenost).

Lapajne $(1987,94)$ je ogroženost (angl. risk) definiral kot »... možne družbene in ekonomske posledice bodočih nesreč. Govorimo o potresni, poplavni, požarni itd. ogroženosti. Ogroženost je verjetnosti pojem in jo lahko opredelimo z verjetnostjo prekoračitve ... Odvisna je od nevarnosti, ranljivosti in od časa izpostavljanja ..." To definicijo uporabljata tudi Đurović in Mikoš $(2006,154)$, vendar pa po mojem mnenju ni dovolj natančna, saj govori o dveh, precej različnih stvareh. V prvem delu govori o »možnih družbenih in ekonomskih posledicah bodočih nesreč«, ki v konkretni pokrajini nastanejo zaradi prisotnosti določene nevarnosti (potresna, poplavna, požarna idr. nevarnost), kar je z geografskega vidika, ki obravnava naravne nesreče kot pokrajinsko sestavino, povsem ustrezna opredelitev ogroženosti. $\mathrm{V}$ drugem delu definicije se pojavi pojem verjetnost prekoračitve, to pa je tveganje in ne ogroženost. Izraza enako razlikuje tudi Smith (2004, 5): »Tveganje (angl. risk) je verjetnost nastopa nevarnosti.«

Slika 4: Hudourniške poplave so resna nevarnost v velikem delu Slovenije. Na sliki je odstranjevanje posledic katastrofalne poplave v Železnikih 18. 9. 2007 (foto: K. Natek; 19. 9. 2007)

Figure 4: Flash floods are a serious threat in many parts of Slovenia. The figure shows the clean up in Železniki after catastrophic floods of September 18, 2007 (photo: K. Natek; 19. 9. 2007)

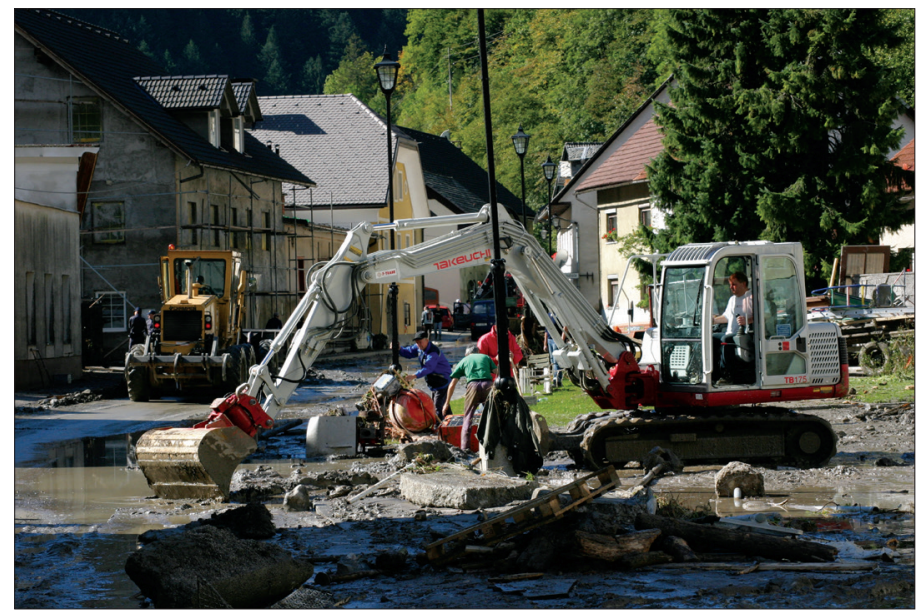

Nevarnosti so torej okoliščine/pogoji na neki določeni lokaciji (Đurović, Mikoš, 2006, 153), ki lahko (ne vedno, ampak ko se izpolnijo določeni pogoji) ogrozijo človeka, objekte in človekove dejavnosti. V kolikšni meri to stanje ogroženosti rezultira v konkretni škodi in drugih posledicah, ni odvisno le od značilnosti nevarnosti (naravne nesreče), njene pogostnosti pojavljanja in magnitude, ampak tudi od občutljivosti ljudi oziroma družbe na te pojave, kar imenujemo ranljivost (angl. vulnerability). Verjetnost 
prekoračitve nekih meja, nad katerimi začne določen naravni dogodek (nevarnost) škodovati človeku oziroma družbi, pa je tveganje, ki ga človek/družba vede ali nevede prevzameta, in ne ogroženost kot jo definira Lapajne $(1987,94)$.

Zakon o varstvu pred naravnimi in drugimi nesrečami (2006) se pri definiranju izraza ogroženost nasloni na splošno rabo iz SSKJ: »Ogroženost je resnična ali občutena izpostavljenost ljudi, živali, premoženja, kulturne dediščine in okolja nevarnostim naravnih in drugih nesreč«. Ni potrebno torej, da se mora »ogroženost realizirati« in šele potem lahko govorimo o nesreči (Đurović, Mikoš, 2006, 156), dovolj je, da ljudje zgolj občutimo izpostavljenost nečemu in je to že ogroženost. Ta pomenska razlika je po mojem mnenju ključna za razločevanje med izrazoma ogroženost in tveganje, zato jih po mojem mnenju ne bi smeli uporabljati kot sopomenki.

Primer snežnih plazov v Trenti nam govori, da v naravi obstajajo nevarnosti in nevarna območja, »ki napovedujejo, da se lahko človeku (ne naravi!) zgodi nekaj neprijetnega ali hudega« in to »pomeni bolj ali manj očitno grožnjo (angl. threat) za človeka in/ ali njegovo imovino, razmere ob prisotnosti takšnih groženj pa imenujemo ogroženost.« (Komac, Natek, Zorn, 2008, 37). Snežni plazovi so torej pomembna sestavina doline Trente in čisto konkretna nevarnost, ki se v določenih situacijah (pozimi, npr. po močnih snežnih padavinah) stopnjuje v neposredno ogroženost zaradi snežnih plazov. Tej nevarnosti se lahko izognemo s premišljeno izbiro lokacije za bivališča in druge objekte, vendar se moramo ob tem zavedati, da je določena stopnja tveganja vseeno prisotna. $\mathrm{Z}$ nepremišljenim ravnanjem lahko že prisotno ogroženost še povečamo.

Ogroženosti tudi ni dobro enačiti z ranljivostjo. Po eni od geografskih definicij je pomenska razlika med izrazoma sledeča: Ogroženost je »stanje v pokrajini, ranljivost pa lastnost določenega objekta, v najširšem pomenu na primer posameznika, hiše, ceste, naselja, tudi ekosistema, rastlinske ali živalske vrste.« (Komac, Natek, Zorn, 2008, 37). Uporaba izraza ranljivost $\mathrm{v}$ zgornjem, širokem pomenu je sicer možna (poznamo npr. tudi ranljivost okolja, prsti, rastja, gospodarstva itd.), vendar pa se v sodobnih preučevanjih naravnih nesreč ta beseda (angl. vulnerability) vse bolj uporablja samo v povezavi s posamezniki, oziroma družbenimi skupinami: »Ranljivost, kot jo razumemo, se nanaša samo na ljudi, ne na zgradbe (te so občutljive, ne-varne), gospodarstvo (krhko), ne na nestabilna pobočja (nevarna) ali na dele zemeljskega površja (izpostavljeni nevarnostim - ogrožena).« (Wisner in sod., 2004, 15).

Primer: v Ljubljani in okolici je stalno prisotna nevarnost potresa in močan potres $\mathrm{v}$ prihodnosti je povsem konkretna grožnja, zaradi katere smo prebivalci neposredno ogroženi. Tega dejstva ne moremo spremeniti; lahko ali še naprej živimo v tem mestu ali se odselimo na potresno manj nevarno območje (npr. v Maribor ali na Goričko), kjer bomo veliko manj ogroženi zaradi potresov. Vendar to ni edina možna rešitev: potem ko so seizmologi določili stopnjo ogroženosti (pravilneje stopnjo nevarnosti; prim. stopnja nevarnosti snežnih plazov) zaradi potresov v Ljubljani, so dosegli, da se pri gradnji objektov upoštevajo ukrepi potresno varne gradnje. S tem se sicer ni nič zmanjšala ogroženost Ljubljane zaradi potresov, pač pa se je (verjetno) izboljšala varnost (trdnost, vzdržljivost) stanovanjskih in drugih zgradb in s tem močno zmanjšala naša ranljivost, ko se bo prej ali slej zgodil močnejši (nevaren) potres. 


\section{TVEGANJE}

V SSKJ je beseda tvegati razložena kot »... za dosego cilja iti v nevarnost a) da se doživi kaj nezaželenega, slabega, ... b) da se izgubi kaj«. Tveganje je torej možnost, povezana z odločitvijo posameznika, družbene skupine ali celotne družbe, da zavoljo nekega cilja sprejme odločitev, pri kateri obstaja poleg koristi tudi določena možnost/verjetnost negativnih posledic. Vsaka odločitev je v življenju sicer povezana z večjo ali manjšo mero negotovosti, saj ocene vedno temeljijo na nepopolnem poznavanju situacije, oziroma izhajajo iz subjektivne presoje in tehtanja. Toda pri odločanju igra pomembno vlogo t.i. sprejemljivo tveganje (angl. acceptable risk), ki ga lahko (tudi v povezavi z naravnimi nesrečami) definiramo kot »možnost dogodka z majhno verjetnostjo pojavljanja in z majhnimi učinki, oziroma s takšnimi ugodnostmi (pričakovanimi ali dejanskimi), da so se posamezniki ali družbene skupine pripravljene izpostaviti tveganju, da se bo dogodek morda zares zgodil.« (Gale Encyclopedia of public health, 2011).

Slika 5: Zemeljski plaz, ki se je sprožil 10. 7. 2009 nad vasjo Lokovica v bližini Šoštanja, je le eden od mnogih na plazovitem območju v oligocenski morski sivici. Gradnja stanovanjske hiše v takšnem svetu predstavlja veliko in stalno tveganje (foto: K. Natek; 12. 7. 2009)

Figure 5: The landslide of July, 10, 2009, above the village Lokovica near Šoštanj is just one of many in the avalanche-prone area in Oligocene marls. Construction of residential houses in such a terrain presents a major and permanent risk (photo: K. Natek; 12. 7. 2009)

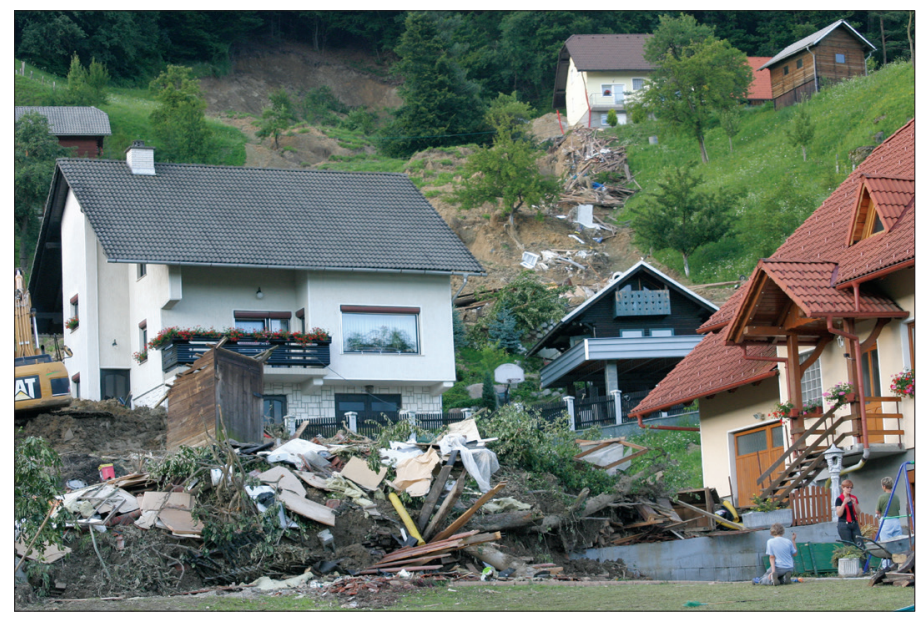

Ker še tako skrbno načrtovanje ali izvajanje varovalnih ukrepov ne more zagotoviti stoodstotne varnosti za vse čase in vse primere, se v tehničnih disciplinah tveganje razdeli na dva dela: prevzeto tveganje (tudi sprejemljivo tveganje) in preostalo tveganje (Kozelj in sod., 2008, 146). Ta delitev je sicer sprejemljiva, a s širšega in tudi geografskega vidika ni povsem prepričljiva, saj se lahko v preostalo tveganje zlahka vključijo tudi negativni učinki načeloma dobronamernih ukrepov varovanja pred naravnimi 
nesrečami. To si lahko nazorno predstavimo na primeru poplav, velja pa tudi za druge vrste naravnih nesreč: pri projektiranju posegov v vodotoke se izhaja iz t.i. projektnega pretoka (npr. $\mathrm{Q}_{50}$ ali $\mathrm{Q}_{100}$ ), to je pretoka, »... na katerega so v projektni dokumentaciji dimenzionirani objekti, naprave in ureditve ...« (Kozelj in sod., 2008, 145-146). Kjer so bili izvedeni vodnogospodarski ukrepi (npr. v naseljih), je torej s projektom določeno, »... do katerega projektnega pretoka mora izvajalec vodne gospodarske javne službe zagotavljati funkcijo (pretočnost) grajenega vodotoka. To imenujemo prevzeto tveganje, saj projektant in izvajalec vodnogospodarske službe prevzameta odgovornost, da ob pretokih do te vrednosti ne bo prišlo do ogroženosti zaradi poplav. Lapajne $(1987,94)$ $\mathrm{v}$ nasprotju s tem mnenjem enači sprejemljivo tveganje s celotnim tveganjem in hkrati z ogroženostjo, s čimer se ni moč povsem strinjati: »Tveganje (angl. acceptable risk) je tista ogroženost, ki jo zavestno sprejmemo kot sprejemljivo. Natančneje je to 'verjetnost prekoračitve', ki jo jemljemo kot osnovo za določitev projektnih zahtev v graditeljstvu ali pri družbenoekonomskih posegih.«

V primeru ekstremnih naravnih dogodkov, zaradi katerih se pojavi večji pretok od projektnega, te odgovornosti ne more prevzeti nihče in se jo pripiše t.i. višji sili. To je t.i. preostalo tveganje, ki ga je sicer možno do neke mere zmanjšati z dodatnimi varnostnimi ukrepi, ne moremo ga pa v celoti izločiti. K temu preostalemu tveganju lahko prištejemo tudi tveganje, ki ga v pokrajino vnaša človek z neustreznimi posegi v naravno kroženje vode, npr. z osuševanjem mokrišč, regulacijami vodotokov, posegi, zaradi katerih se je povečal dotok plavin v vodotoke, itd.

Pri takšnem, izrazito tehničnem pristopu k zmanjševanju tveganja obstaja namreč velika nevarnost, da se zapletemo v krog vedno novih ukrepov, ki poleg pozitivnih učinkov prinašajo tudi vse večjo ogroženost. Na to je že pred več kot 60 leti opozoril ameriški geograf G. White (White in sod., 1974, 3): »Te analize so v Združenih državah leta 1957 privedle do ugotovitve, da se je v 20 letih po sprejetju Zveznega zakona o obvladovanju poplav (1936) kot neto učinek velikih investicij zvezne vlade v gradnjo protipoplavnih objektov (jezovi, regulacije rečnih strug in protipoplavni nasipi) povečala škoda zaradi poplav na območjih, na katerih so v tem času porabili več kot pet milijard dolarjev za preprečevanje in zmanjšanje škode zaradi poplav.«

Medtem ko je ogroženost stalno prisotna sestavina pokrajine, moramo pri izrazu tveganje nujno upoštevati družbenogeografski vidik, oziroma natančneje opredeliti stališče, s katerega opredeljujemo tveganje: ali z vidika posameznika, določene socialne skupine, prebivalcev določenega območja ali celotne družbe. Tveganje namreč v celoti izhaja iz človeka, iz njegove zavestne (hotene) pa tudi nehotene odločitve, da se izpostavi določeni nevarnosti. Avtonomnost odločanja posameznika je seveda močno omejena z njegovimi individualnimi značilnostmi, predvsem z zmožnostjo zaznavanja nevarnosti, družbenim statusom/materialnim stanjem, ter s splošnimi družbenimi razmerami. Po vsaki večji naravni nesreče se v strokovni in širši javnosti vedno postavlja vprašanje, kdo je kriv za posledice, saj so se prizadeti ljudje vendarle 'prostovoljno' odločili, da bodo živeli na ogroženem območju. To 'prostovoljnost' je zelo težko natančno definirati, brez dvoma pa je v veliki meri pogojena z družbenim položajem prizadetih (Wisner in sod., 2004, 13). 
Lep primer socialne dimenzije tveganja imamo na poplavno ogroženem območju v južnem delu Ljubljane: na poplavni ravnici na levem bregu Malega grabna je po letu 1965 nastalo urbanistično enovito zasnovano stanovanjsko naselje Murgle z nizkopritličnimi enodružinskimi hišami, ki je zaradi družbenega statusa dela prebivalcev kmalu dobilo pridih nekakšnega 'elitnega' naselja, vanj pa so se prostovoljno priselili ljudje z ustreznim finančnim stanjem. Na drugi strani potoka sta na poplavni ravnici med Malim grabnom in Ljubljanico mestna dela Sibirija in Rakova Jelša, kamor so se v preteklosti s povsem drugačno 'prostovoljnostjo' naseljevali revnejši sloji prebivalstva in si tu postavili, večinoma na črno (pozneje legalizirano), bivališča na zelo nevarnem poplavnem območju. Ogroženost zaradi poplav je na obeh bregovih enaka, velike pa so razlike $\mathrm{v}$ razlogih za prevzem tveganja in tudi v ranljivosti, saj so prebivalci nizkih hiš v Murglah bolj ranljivi kot prebivalci visokopritličnih ali enonadstropnih hiš v Sibiriji in Rakovi Jelši.

Slika 6: Poplavna ravnica na desnem bregu Gradaščice pri Dobrovi, kjer je predvidena gradnja suhega zadrževalnika, s katerim naj bi zmanjšali poplavno ogroženost južnega dela Ljubljane (foto: K. Natek)

Figure 6: Floodplain on the right bank of Gradaščica River near Dobrova at the site of planned flood-control reservoir, which should reduce the risk of flooding in the southern part of Ljubljana (photo: K. Natek)

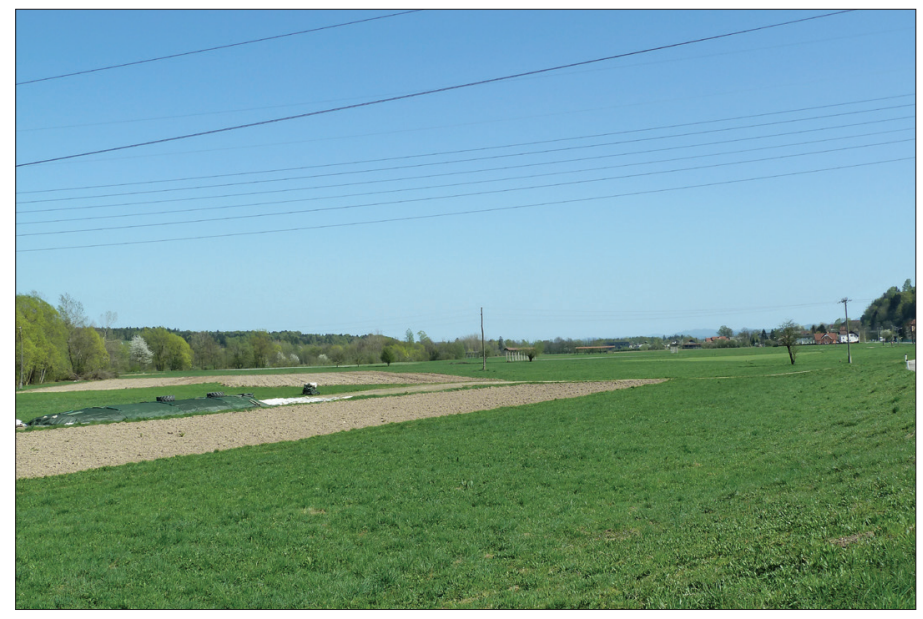

Drug primer je iz držav v razvoju: v velikih mestih so barakarska naselja na ali v neposredni bližini odlagališč odpadkov izpostavljena velikim nevarnostim (požari, strupeni plini, blatni tokovi, onesnažen zrak, onesnažena voda). Ogroženost zaradi naštetih nevarnosti je izjemno velika, toda za tamkajšnje prebivalstvo, ki se bori za preživetje na skrajnem robu družbe, so to najboljše lokacije, saj jim je zbiranje še uporabnih odpadkov edini vir skromnih prihodkov. Elitnemu družbenemu sloju je tveganje, ki so mu te skupine izpostavljene, povsem nepomembno, tudi z vidika države je tveganje prav tako 
neznatno, saj država tej družbeni skupini ne posveča nikakršne pozornosti, prebivalci nimajo nobenega premoženja, tako da je škoda v primeru nesreče neznatna, omejena zgolj na reševanje morebitnih preživelih.

\section{RANLJIVOST}

Gams je v uvodnem prispevku na prvem znanstvenem simpoziju o naravnih nesrečah v Sloveniji $(1983,10)$ zapisal: »Ni razlogov za mišljenje, da so se naravni pojavi, ki lahko postanejo naravne nesreče, v novejšem času kot celota povečali ali zmanjšali. Nedvomno pa je postala naša skupnost zadnje čase bolj ranljiva.«

Naj za izhodišče opredelitve pojma ranljivost navedem dva primera: pozimi se v visokogorju od nekdaj pojavljajo snežni plazovi - običajni naravni pojavi, ki sicer vplivajo na naravne razmere v gorah (npr. lokalno znižujejo zgornjo gozdno mejo ali prispevajo $\mathrm{k}$ transportu preperelega materiala po pobočjih v dolino), a za človeka predstavljajo tudi veliko nevarnost. Izpostavljanje tem nevarnostim je po Gamsovem mnenju $(1983,10)$ ranljivost, ta pa se je močno povečala, oziroma, postali smo bolj ranljivi zaradi njihovega pojavljanja, saj »... kmetovalci, ki so izkoriščali zaradi plazov ogrožena zemljišča, pozimi v ta svet niso zahajali, po izkušnjah pa so se naučili postavljati senike in druge stavbe na varno. $\mathrm{V}$ industrijski dobi smo alpski svet popolnoma prevrednotili in njegov poglavitni pomen je zdaj v rekreaciji za dolinskega človeka. Smučar, gozdar ali lovec prihajajo v gore tudi pozimi. Za množico ljudi v tujem okolju so zdaj Alpe mnogo bolj nevarne kot nekdaj.«

Drug primer je iz vsakdanjega življenja: kot udeleženci v prometu se vsakodnevno izpostavljamo nevarnostim, ki prežijo na nas bodisi zaradi naravnih dejavnikov (gosta megla, poledica, snežne padavine, itd.), bodisi s strani drugih udeležencev. Čeprav je na cestah nevarno, se je naša ogroženost $\mathrm{z}$ izgradnjo avtocest močno zmanjšala, a vožnja po njih še vedno ostaja tvegana, predvsem zaradi brezvestnih ali pijanih voznikov, vendar je tveganje očitno v okvirih sprejemljivega. Na te zunanje okoliščine ne moremo veliko vplivati, je pa, statistično gledano, verjetnost nesreče odvisna od števila prevoženih kilometrov in ranljivosti posameznika. Ta je različna, »kadar se vozim po cesti z avtom, ko sem manj ranljiv, ali pa s kolesom, ko sem bolj izpostavljen in zato veliko bolj ranljiv.« (Komac, Natek, Zorn, 2008, 37)

Pomensko razliko med tveganjem in ranljivostjo izpostavlja tudi Alexander (1999, 13): »Ranljivost je potencial za žrtve, uničenje, škodo, motnje in druge oblike izgube določene sestavine, tveganje pa je kombinacija tega z verjetno stopnjo izgub, ki jih lahko pričakujemo od napovedljive magnitude nesreče.«

Po SSKJ je ranljivost »lastnost, značilnost ranljivega: ranljivost organa, telesa«, ranljiv pa pomeni »ki se da (lahko) raniti: ranljiva mesta na telesu; oko je zelo ranljivo«. $\mathrm{V}$ tem splošnem pomenu ranljivost ni neka zunanja okoliščina (kot npr. ogroženost), ampak je lastnost živega bitja (lahko tudi drugih stvari), odvisna od njegovih fizioloških, psiholoških, družbenih idr. značilnosti. Tudi ne pomeni nekakšnega pričakovanja prihodnjih izgub ali poškodb, saj se svoje ranljivosti večinoma ne zavedamo in jo znamo z določenimi psihološkimi prijemi tudi uspešno zanikati (Polič, 2010, 142-143). 
Čeprav bi bilo koristno izraz ranljivost omejiti zgolj na antropogeni/družbeni vidik, se je izraz uveljavil tudi že na drugih področjih, mdr. pri varstvu okolja in v prostorskem načrtovanju. Izraz ranljivost prostora se je pojavil v Navodilu o vsebini in metodologiji izdelave strokovnih podlag in prostorskih sestavin planskih aktov občin, kjer je ranljivost prostora opredeljena kot »lastnost prostora, izražena z možnimi negativnimi vplivi predvidene dejavnosti na naravne in z delom pridobljene vrednote okolja. Pri določanju stopnje ranljivosti je treba upoštevati pogoje, ki izhajajo iz značilnosti, iz dosedanje namenske rabe, obremenitve okolja in ogroženosti prostora, ter normative in standarde dopustnih obremenitev okolja.« (Navodilo, 1985; cv: Špes in sod., 2002, 20). V poznejši geografski rabi se je pri preučevanju ranljivosti okolja izraz osredotočil na »lastnost okolja, od katere je odvisno, kako se bo to odzvalo na načrtovane posege. «(Špes in sod., 2002, 21). Ta pomen ne odstopa bistveno od tu obravnavane ranljivosti zaradi naravnih nesreč, le da je 'subjekt' ranljivosti v tem primeru okolje kot takšno.

V starejšem Zakonu o varstvu okolja (1993) izraz ranljivost okolja sicer ni posebej definiran, je pa zakon predvidel izdelavo študij ranljivosti okolja, ki naj bi poleg ostalega vključevale tudi »... njegovo občutljivost glede posegov v okolje ...«. Ob tem času so se vodile živahne razprave o pojmu ranljivost (okolja, prostora) med različnimi strokami (geografi, krajinskimi arhitekti, prostorskimi planerji, urbanisti, idr.) vendar pa so se mnenja razhajala glede vprašanja, ali je ranljivost (okolja, prostora) notranja značilnost, ki obstaja, še preden se pojavi določena grožnja ali poseg, ali je to lastnost, ki jo lahko opredelimo šele, ko vanj posežemo ali v njem razvijamo določeno dejavnost, ali je to celo samo »vrednostna ocena stanja okolja, ki razkriva, kje v prostoru so $\mathrm{z}$ vidika varstvenih zahtev manj ustrezna mesta za posege, za katere se išče lokacija ... «(Plut, 2004, 156).

V novi verziji istega zakona (2004) se izraz ranljivost okolja pojavi samo še enkrat, saj se je izkazalo, da izdelava ocene ranljivosti okolja zaradi določenih interesov "ni potrebna', a je izraz ostal v Geografskem terminološkem slovarju $(2005,328)$.

Iz strokovne in splošne rabe poznamo še izraze podnebna ranljivost, ranljivost kmetijstva, ranljivost prostora, ranljivost bančnega sektorja, itd., vendar naj bi pri preučevanju naravnih nesreč ranljivost razumeli kot značilnost posameznika ali družbene skupine.

Lapajne $(1987,94)$ definira ranljivost kot "pričakovano stopnjo izgub (ali poškodb) danega ogroženca ali skupine ogrožencev ob morebitni nesreči. Govorimo o potresni, poplavni, požarni itd. ranljivosti.« $\mathrm{S}$ tem se ni moč povsem strinjati, saj je ranljivost na ta način opredeljena 'od zunaj' (kdo pričakuje to 'stopnjo izgube ali poškodbe'?), večina raziskovalcev pa meni, da je ranljivost izrazito družbena kategorija. Ob enaki ogroženosti je namreč lahko ranljivost posameznika, družbenih skupin ali celotne družbe zelo različna "zaradi različnih načinov delovanja družbenih sistemov, ki vodijo v nesrečo $\mathrm{s}$ tem, da delajo ljudi ranljive.« (Wisner in sod., 2004, 10). Ogroženost je rezultat zunanjih okoliščin v pokrajini, sicer težko natančno določljiva, a jo je mogoče do neke mere izmeriti (npr. poplavna, potresna ogroženost, ogroženost zaradi zemeljskih plazov, vremenskih ujm), ranljivost pa je dovzetnost/občutljivost posameznika za negativne posledice dogodkov, ki se bodo z določeno verjetnostjo zgodili. Ima pa ranljivost tudi časovno dimenzijo - ne nanaša se le na trenutno stanje, ampak tudi na prihodnje učinke naravnih dogodkov/nesreč na družbeno skupino (Wisner in sod., 2004, 12). 
Slika 7: S postavitvijo novih stanovanjskih hiš prizadetim zaradi drobirskega toka 17. 11. 2001 v varnejši legi se je močno zmanjšala ranljivost prebivalcev Loga pod Mangartom (foto: K. Natek)

Figure 7: The construction of new houses for families affected by the debris flow of November 17, 2001, in a safer position, has considerably reduced the vulnerability of the inhabitants of Log pod Mangartom village (photo: K. Natek)

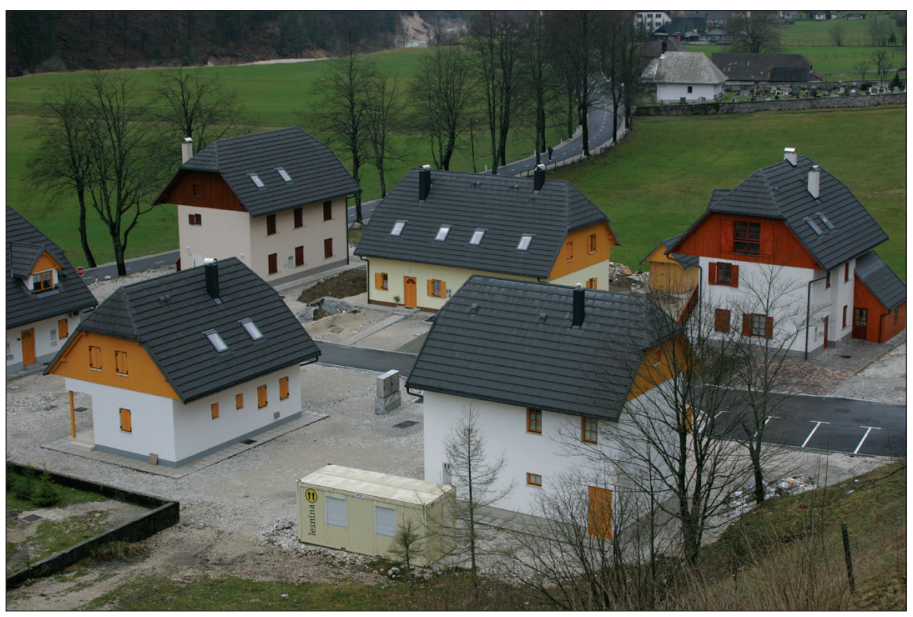

Stanovanjska hiša na poplavnem območju je torej a priori ogrožena zaradi poplav, stopnjo ogroženosti je možno določiti s pogostnostjo, intenzivnostjo in drugimi značilnostmi poplav na tem območju. Ranljivost njenih stanovalcev pa ima dva različna vidika: odvisna je od njihovega družbenega položaja (materialno stanje, socialne razmere) in od tega, v kolikšni meri so se prilagodili obstoječim danostim z načinom gradnje in drugimi preventivnimi ukrepi, ki so jih uveljavili že pred nastopom dejanske poplave (npr. gradnja na umetno nasutem zemljišču ali na stebrih, vodotesna vrata, ustrezna izvedba tal v pritličnih prostorih, pravilno projektirana kanalizacija, višje nadstropje, kamor se lahko umaknejo v primeru poplave, itd.). Lokacija je bila torej poplavno ogrožena že pred postavitvijo hiše, s svojimi odločitvami pa so se ljudje sami, vede ali nevede, spravili v stanje ranljivosti in tega ni kriva 'kruta narava' (Alexander, 1999, 7; Komac, Natek, Zorn, 2008, 37).

Wisner in sod. $(2004,11)$ definirajo ranljivost kot »značilnost posameznika ali skupine in njihovega položaja, ki vpliva na njihovo zmožnost predvidevanja, soočanja z, preprečevanja in premagovanja posledic naravne nesreče (izjemnega naravnega dogodka ali procesa). Vključuje kombinacijo dejavnikov, ki določajo stopnjo, do katere so življenje, vsakdanje preživetje, imovina in drugo izpostavljeni tveganju zaradi poznanega dogodka (ali niza takšnih dogodkov) v naravi in družbi.«

Wisner in sod. $(2004,17)$ opozarjajo še na en vidik ranljivosti v sodobnih 'družbah izobilja'. Za razliko od revnih držav, kjer je ranljivost zelo prisotna v vsakodnevnem življenju (npr. poplave v času poletnega monsuna v Južni Aziji), se v razvitejših družbah z 
visokim življenjskim standardom večine prebivalstva, dobro organiziranim javnim sektorjem, razvitimi storitvenimi dejavnostmi in vsemi razpoložljivimi oblikami varstva, od vojaške varnosti do varstva človekovih pravic, občutek ranljivosti izgublja, saj ljudje številnih nevarnosti sploh ne moremo več občutiti z lastnimi čutili (dotikom, vidom, vohom). Zaradi tega prihaja do vse bolj očitnega protislovja: tudi pod vplivom medijev se povečuje občutek ranljivosti pred globalnimi dogodki (terorizem, nesreča $\mathrm{v}$ jedrski elektrarni, globalne klimatske spremembe), ranljivost pred 'lokalnimi' dogodki (poplave, plazovi, vremenske ujme) pa se vse bolj izgublja iz zavesti prebivalstva, čeprav nas te veliko bolj ogrožajo.

Beck $(1992,4)$ je že pred leti opozoril na pomemben sociološki vidik ranljivosti, ki se med drugim kaže v vse manjši odpornosti oziroma prožnosti družbe v primeru naravne nesreče: »Največje tveganje je, tudi za najbolj tehnično intenzivne dejavnosti (in morda še posebno za te), v družbeni odvisnosti od inštitucij in akterjev, ki so lahko - in dokazano vse bolj - odtujeni, skriti in nedostopni večini prebivalstva, ki je izpostavljeno temu tveganju.« $\mathrm{S}$ tem se naša ranljivost bistveno povečuje, saj se povsem zanašamo na družbene/državne sisteme (npr. izdajanje gradbenih dovoljenj za gradnjo stanovanjskih hiš), ali pa jih poskušamo izigrati v lastno kratkoročno korist (npr. črne gradnje na poplavnem območju in poskusi kasnejših legalizacij, neupoštevanje določil gradbenega dovoljenja).

Slika 8: K zmanjšanju ranljivosti družbe pomembno prispevajo dobro organizirane in usposobljene enote za zaščito in reševanje; na sliki gasilci med vajo 'Potres Idrija 2011' 26. 3. 2011 (foto: K. Natek)

Figure 8: Well organized and trained search and rescue units considerably reduce the vulnerability of population; members of a fire brigade during the exercise IIrija Earthquake 2011' in the town of Idrija (photo: K. Natek; 26. 3. 2011)

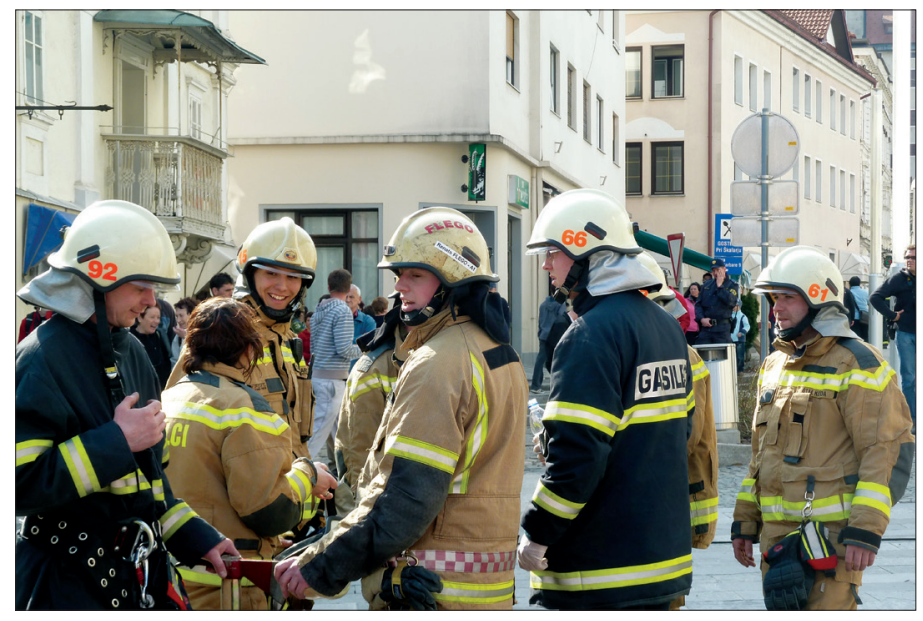




\section{PRILAGODLJIVOST IN PROŽNOST}

Skozi vso zgodovino se je moral človek kot posameznik in kot del določene družbene skupine neprestano soočati in prilagajati spremembam v okolju. Vse do industrijske revolucije in v agrarni družbi še vse 19. st. in prvo polovico 20. st. so bili ljudje zelo neposredno odvisni od naravnih danosti in lokalnih naravnih virov, ki so jih nujno potrebovali za vsakdanje preživetje. Morali so obvladati veščine neposrednega zaznavanja procesov v naravi in prilagajanja spremembam, kar se je z delom generacij vgradilo tudi v okolje/pokrajino. Mnoge od teh sestavin so postale neločljiv sestavni del naših pokrajin, vključno z različnimi načini prilagajanja naravnim danostim in omejitvam, tudi naravnim nesrečam (Natek, 2002, 63).

Slika 9: Vitek most s širokim prepustom na Ljubnem, zgrajen po ujmi novembra 1990, je ustrezna prilagoditev hudourniški naravi reke Savinje (foto: K. Natek)

Figure 9: Slender bridge with wide span in Ljubno, built after the floods of November 1, 1990, is well suited to torrential temper of Savinja River (photo: K. Natek)

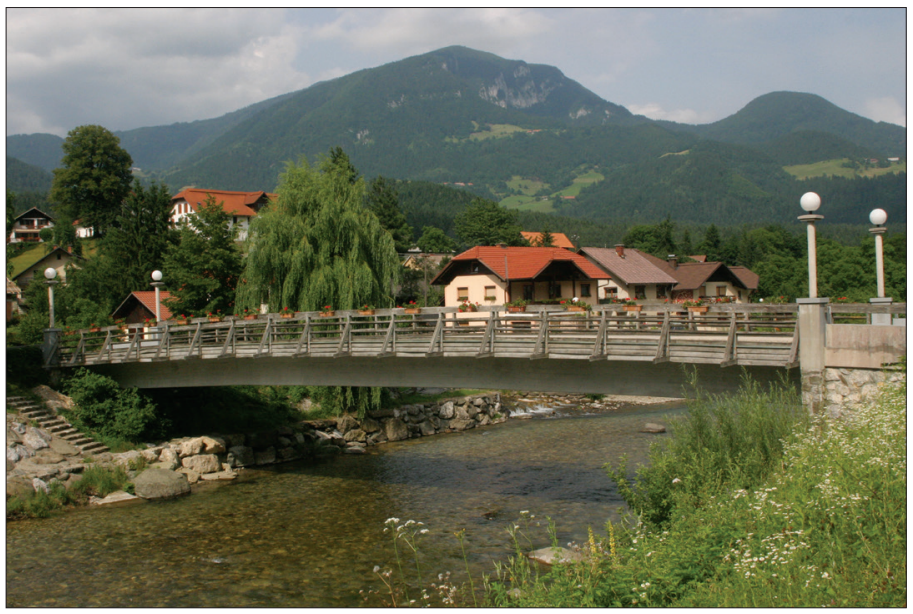

Zapleteni vplivi med naravo in družbo so dvosmerni, vendar se moramo pri preučevanju naravnih nesreč izogibati determinizmu, ki se kaže v miselnosti, da je narava 'kruta' in 'neusmiljena', ljudje pa smo njene nemočne žrtve in ne moremo ničesar storiti. Človek je svoje sposobnosti prilagajanja že neštetokrat dokazal, bolj zaskrbljujoč je v sodobnih družbah vse bolj prisoten indeterministični pristop, ki zanika kakršen koli vpliv okolja na družbo (Wisner in sod., 2004, 10). Pri naravnih nesrečah se to kaže v vse manj prisotnem občutku ranljivosti, v prepričanju, da lahko s tehničnimi in drugimi sredstvi preprečimo vse negativne učinke naravnega dogajanja, v vse manjši sposobnosti prilagajanja zunanjim okoliščinam in v vse bolj omejenih zmožnostih odzivanja na negativne učinke naravnih procesov (angl. resilience $=$ prožnost).

Osnovna razlika med prilagajanjem in prožnostjo je v tem, da je prilagajanje trajen proces, s katerim pridobiva posameznik ali družbena skupina »... lastnosti, značilnosti glede na 
okoliščine, navadno zaradi obstoja ...« (SSKJ), prožnost pa je »... sposobnost prilagajati se času, razmeram ...« (SSKJ). Pri prilagajanju človek ni nemočen, ampak si okolje od nekdaj preoblikuje v skladu s svojimi potrebami in zmožnostmi. Ključna za preživetje je bila ravno sposobnost prepoznavanja nevarnih območij in izogibanja posegov vanje (Natek, 2002, 65).

V sodobni družbi je velik del prilagajanja naravnim danostim prevzela država, saj se zaradi zelo različnih individualnih in drugih parcialnih interesov v omejenem prostoru $\mathrm{z}$ omejenimi naravnimi viri pojavljajo konflikti med uporabniki, ki jih mora urejati država, oziroma njeni upravni organi. Najprimernejši način prilagajanja naravnim danostim (tudi naravnim nesrečam) je ustrezno prostorsko načrtovanje, ki bi moralo vključevati tudi potrebne preventivne ukrepe za zmanjšanje ranljivosti (Kozelj in sod., 2008, 145). Če sodobna družba ne zna prepoznati in pravilno razumeti naravnih nesreč kot sestavnega dela pokrajine, ostaja prostorsko načrtovanje shematično, neprilagojeno konkretnim pokrajinskim značilnostim (naravnim in družbenim), navezano na parcialne tehnične rešitve, ki kljub velikim finančnim sredstvom ne zagotavljajo ustrezne stopnje varnosti. Dolgoročno obliko sobivanja z naravnimi nevarnostmi bomo dosegli, če se »... jim bomo izognili, ne pa omejevali ali celo preprečevali naravni proces, saj je slednje pogosto ekonomsko in okoljsko nesprejemljivo.« (Komac, Zorn, Pavšek, 2010, 9).

Izogibanje območjem, kjer so naravni procesi posebno intenzivni in (za človeka) nevarni, je najpopolnejši način prilagajanja naravnim danostim. Čeprav cilj tega ni varovanje narave, ampak varovanje človeka (družbe) pred škodljivim delovanjem naravnih procesov (Natek, 2007, 154), to omogoča dolgoročni trajnostni razvoj ob minimalnih stroških 'urejanja' narave in preprečuje nastajanje morebitne škode ali celo človeških žrtev.

Slika 10. Vozkem dolinskem dnu ob Davči se hudourniškim poplavam ni mogoče izogniti. Na sliki posledice poplave 18. 9. 2007 (foto: K. Natek; 23. 9. 2007)

Figure 10: In a narrow valley bottom of Davča brook, the torrential floods can not be avoided. The figure shows the consequences of floods of September 18, 2007 (photo: K. Natek; 23. 9. 2007)

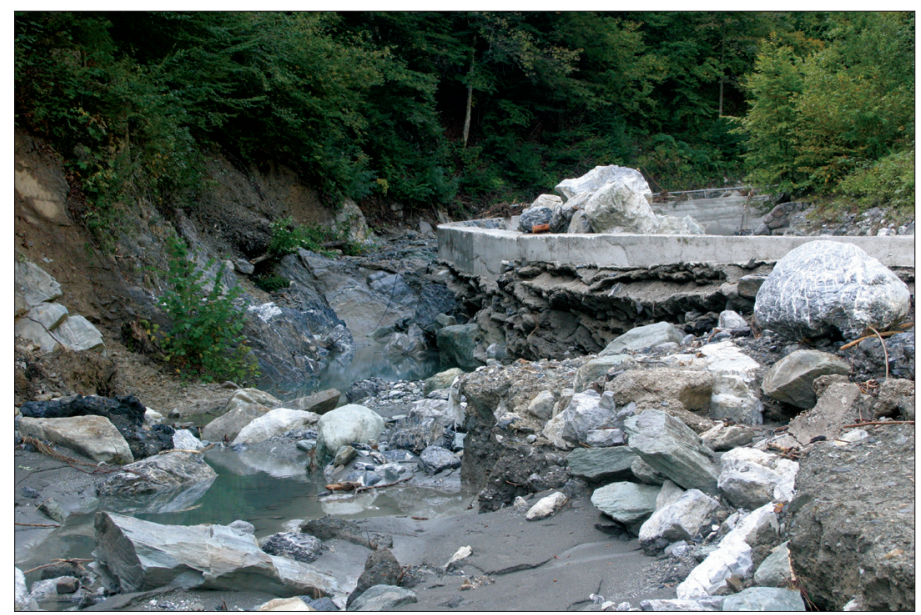


V Sloveniji smo v tej smeri naredili pomemben korak s sprejetjem Strategije prostorskega razvoja Slovenije (2004), vendar pa se tehtna določila strategije zaradi drugačnih interesov le v manjši meri upoštevajo pri izdelavi sedanje generacije občinskih prostorskih načrtov. V tem dokumentu je jasno zapisano, kako se najustrezneje prilagoditi destruktivnim naravnim procesom: »Naravne procese, ki lahko ogrožajo poselitev in človekove dejavnosti, se obvezno upošteva kot omejitev pri načrtovanju rabe in dejavnosti v prostoru. Prostorski razvoj na vseh območjih, zlasti pa na ogroženih območjih, se načrtuje v skladu z omejitvami zaradi naravnih in drugih nesreč, kot so poplave, zemeljski in snežni plazovi, erozija, požari v naravnem okolju in potresi. Potencialna tveganja se zmanjšuje s preventivnim načrtovanjem, in sicer $\mathrm{z}$ razmeščanjem dejavnosti $\mathrm{v}$ prostor izven območij potencialnih nesreč, $\mathrm{z}$ ustreznim upravljanjem primarnih dejavnosti $\mathrm{v}$ nevarnih in ogroženih območjih ter z nadzorovanjem aktivnosti, ki lahko povzročajo naravne in druge nesreče." (Strategija, 2004, 30).

Premajhno upoštevanje smernic Strategije prostorskega razvoja Slovenije je razvidno že iz bežnega vpogleda $v$ te prostorske dokumente, zato smo še zelo daleč od uresničitve naslednje zahteve, ki je ključnega pomena za uspešnejše prilagajanje naravnim danostim: »Uporaba prostora mora odražati oziroma se prilagajati njegovi ogroženosti, urbanistični dokumenti pa morajo vzpostaviti varovanje prostora pred nenačrtnimi in nezadostno premišljenimi posegi, ki lahko bistveno spremenijo njegovo funkcioniranje ob morebitnih naravnih in drugih nesrečah.« (Jeraj, 2010, 227).

Prožnost je pri preučevanju naravnih nesreč novejši izraz, čeprav se uporablja tako v splošni rabi kot v strokovnih krogih (npr. v fiziki, logistiki, bančništvu, managementu). SSKJ navaja dva pomena besede, ki sta pomembna za tukajšnje razmišljanje: »1. lastnost prožnega telesa ali snovi: prožnost jekla ... 4. ekspr. sposobnost prilagajati se času, razmeram«. Prvi pomen je zelo star in povsem jasen: »Sploh je pri grajenji treba gledati na prožnost gradiva, da se hiše lahko majejo in protisunki potem niso prehudi. " (Stavbe po potresu, 1895). Drugi, ekspresivni pomen zelo neposredno zadeva odnos med človekom/družbo in naravnimi nesrečami, na njegovi osnovi lahko definiramo prožnost kot sposobnost posameznika, družbene skupine ali celotne družbe, da se na ustrezen način sooči, odzove in prilagodi negativnim posledicam naravne nesreče.

Natančnejša opredelitev pomena besede prožnost ni enostavna, saj se tudi pri preučevanju naravnih nesreč uporabljajo besede s sorodnimi pomeni. Zaključni dokument drugega simpozija Naravne nesreče v Sloveniji, ki je potekal 25. marca 2011 na Igu (Drugi simpozij ..., 2011) navaja v enem stavku tri sorodne besede: »Njen (platforme za naravne nesreče, op. pisca) temeljni cilj bo povečanje odpornosti ali prožnosti oziroma odzivnosti družbe (angl. resilience) na naravne nesreče na vseh ravneh ...«. Po mojem mnenju je beseda prožnost med temi tremi najustreznejša, saj vsebuje tudi pomene ostalih dveh: odpornost je namreč po SSKJ »lastnost, značilnost odpornega« (npr. odpornost organizma, odpornost proti boleznim, odpornost materiala proti obrabi), odporen pa med drugim pomeni »sposoben, usposobljen prenesti negativne okoliščine, vplive« (npr. jabolka, odporna proti pozebi). Odzivnost je po istem slovarju »lastnost, značilnost odzivnega«, odziven pa je »sposoben (hitro) se odzivati«. Prvi izraz (odpornost) torej posredno pomeni stopnjo prožnosti, drugi (odzivnost) pa 
intenzivnost ter hitrost odziva na negativne učinke naravnih nesreč, kar pa je lahko v celoti vsebovano v izrazu prožnost.

Zlasti v povezavi s poplavami se v zadnjih letih, posebno po uveljavitvi evropske direktive o poplavah (Direktiva, 2007), vse bolj zagovarja kompleksnejši pristop k obravnavanju poplav, s katerim naj bi presegli klasični, v veliko primerih neuspešen pristop. Mikoš $(2010,256)$ ugotavlja, da ta novi pristop »... vsebuje vrsto regulatornih, socialnih in ekonomskih odzivov (angl. responses) ...« in »V tem duhu se vse bolj uporablja tudi izraz odpornost (angl. resilience), ki predstavlja novi način razmišljanja o upravljanju tveganj. Odpornost je pri tem mišljena kot sposobnost (zmožnost) sistema (družbe) ali posameznika, da nadaljuje in se razvija na socialno sprejemljiv način, kadar je podvržen stresnim razmeram ali nezgodam.«

Definicija je sicer povsem v redu, vendar ima ta beseda že v več strokah jasno opredeljen pomen, npr. odpornost na bolezen ali odpornost na zdravila (Kraigher, Pahor, 2002), potresna odpornost stavb (Tomaževič, 2002; Lutman, Zupančič, Šket Motnikar, 2010), odpornost gozdnih sestojev (Klopčič, Poljanec, Bončina, 2010), odpornost objektov na poplavne vode (Kozelj in sod., 2008). Tudi za sistem nacionalne varnosti je bolje, da je prožen in prilagodljiv kot odporen, saj »Dinamično spreminjanje sodobnega varnostnega okolja ter kompleksnost varnostnih groženj in tveganj v njem zahtevajo tudi organizacijsko povezanost posameznih resornih politik ... ter organizacijsko prožnost in prilagodljivost sistema nacionalne varnosti in njegovih podsistemov.« (Resolucija o strategiji nacionalne varnosti ..., 2010, 49). Zatorej bi bilo po mojem mnenju bolje, da pri naravnih nesrečah v zapletenih interakcijah med naravo in človekom/družbo namesto izraza odpornost rajši uporabljamo izraz prožnost.

Slika 11: S kamni obložene strehe na Kidričevi ulici v Ajdovščini so odlična prilagoditev orkanski burji (foto: K. Natek)

Figure 11: The stone-coated roofs in the Kidrič Street in Ajdovščina are an excellent adaptation to strong bora wind (photo: K. Natek)

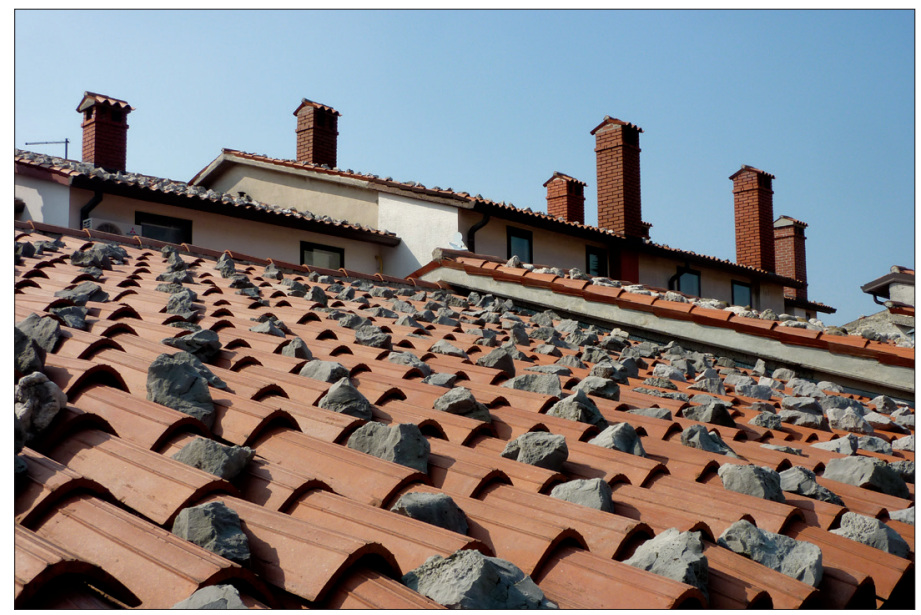


Temu v prid lahko dodamo še dve pomenski razliki med besedama: odpornost je bolj statična (npr. hiša je odporna proti potresom, vendar se lahko ob močnem potresu poruši in je vsega konec), človeško družbo pa si lahko predstavljamo kot izrazito prožno, saj ima lastnosti, ki ji omogočajo, da v stresnih razmerah ali ob nesrečah absorbira negativne učinke naravne nesreče in se lahko razvija naprej. Človek kot živo bitje je odporen proti najrazličnejšim boleznim, pri psiholoških odzivih na nesrečo pa ne moremo govoriti o odpornosti, temveč zgolj o prožnosti, saj »... Tudi če je reakcija posameznika (ljudi) ob nesreči videti ekstremna, skoraj nikoli ne preide v kronične težave. Pravzaprav je prav ta prožnost ljudi po nesreči ena poglavitnejših značilnosti nesreč in obnove stanja po nesreči. Še več, posledice takšnih dogodkov prinesejo celo nekaj pozitivnih lastnosti oz. stanj. Ljudje se pogosto šele ob nesreči zavedo, kako močni so in koliko bremena lahko prenesejo.« (Badovinac, 2007, 247).

\section{SKLEP}

Naravne nesreče so izredno kompleksen geografski pojav, pomembna sestavina zapletenega, dvosmernega součinkovanja naravnih in družbenih dejavnikov v pokrajini. Ti odnosi delujejo na družbo na najrazličnejše načine in na različnih ravneh, od individualne do globalne, dojemanje teh povezav na nivoju posameznika, družbene skupine ali družbe pa je zelo raznovrstno in izrazito subjektivno. To se kaže tudi v izrazih, s katerimi poskušamo opredeliti te povezave, saj zaradi zapletenosti naravnih nesreč in odnosa družbe do njih težko pridemo do poenotene rabe temeljnih strokovnih terminov. Temeljni izrazi nimajo samo semantične, pomenske razsežnosti, ampak vključujejo tudi ključne paradigme in metodologijo znanstvene stroke, ki jih uporablja. In ker se z naravnimi nesrečami kot izrazito interdisciplinarnim področjem ukvarjajo tako naravoslovne kot družboslovne vede, in seveda geografija, je težava pri sporazumevanju na nivoju temeljnih izrazov še toliko hujša.

V geografiji naravnih nesreč izhajamo pri določanju pomena temeljnih pojmov iz ugotovitev, da so naravne nesreče sestavni del pokrajine/okolja/prostora in specifičen del zapletenih odnosov med človekom/družbo in naravo. Skoraj vsi v prispevku obravnavani izrazi se nanašajo na človeka/družbo, oziroma njegov odnos do narave, v naravi obstajajo samo določeni procesi, pojavi, okoliščine, stanje, možnost, zaradi katerih lahko pride do nekega končnega dogodka, ki ima lahko (to je naravna nesreča), ali tudi ne, negativne posledice za človeka/družbo.

Prisotnost takšnih ali drugačnih nevarnosti v pokrajini in njihovo težavno dojemanje in razumevanje predstavlja za človeka/družbo določeno grožnjo. Temu se nikakor ne moremo povsem izogniti (lahko pa te grožnje elegantno zanikamo), zato v večji ali manjši meri tvegamo, da bomo zaradi naše prisotnosti v pokrajini, bolj ali manj polni nevarnosti, doživeli neke negativne posledice. Kljub razsežnosti nekaterih nevarnosti (npr. potresna nevarnost, nevarnost tsunamija) nismo povsem nemočni, saj lahko verjetne/pričakovane negativne učinke v veliki meri vnaprej ublažimo tako, da zmanjšamo našo ranljivost (npr. s potresno varno gradnjo), oziroma se prilagodimo obstoječim naravnim danostim in omejitvam, mdr. z izogibanjem nevarnim območjem ali nasploh z dobro premišljenim poseganjem v pokrajino. 
Naj si človek/družba še tako prizadeva na vse mogoče načine 'očistiti' pokrajino vsakršnih groženj, nam to ne bo nikoli v celoti uspelo, zato moramo na nivoju slehernega posameznika in celotne družbe poskrbeti, da bomo pri soočanju z negativnimi učinki naravnih nesreč in pri prilagajanju za nas neugodnim naravnim danostim dosegli največjo možno stopnjo prožnosti, torej na čim manj boleč način v 'normalno' delovanje družbe in naše vsakdanje življenje vključili po magnitudi, kraju pojavljanja in drugih značilnostih 'nenormalne' naravne procese oziroma dogodke.

\section{Viri in literatura}

Alexander, D. C., 1993. Natural disasters. London, UCL Press, 632 str.

Alexander, D. C, 1999. Natural disasters. Dordrecht, Kluwer Academic Publishers, 633 str. Badovinac, V., 2007. Pomen psihološke pomoči ob naravnih nesrečah. Ujma, 21, str. 246-255. Ljubljana.

Beck, U., 1992. Risk society: towards a new modernity. London, Sage, 260 str.

Boteler, D. H., Pirjola, R. J., Nevanlinna, H., 1998. The effects of geomagnetic disturbances on electrical systems at the Earth's surface. Advances in space research, 22, 1, str. 11-21. Oxford, New York.

Direktiva 2007/60/ES Evropskega parlamenta in Sveta z dne 23. oktobra 2007 o oceni in obvladovanju poplavne ogroženosti. Uradni list EU, L 288/27 (6. 11. 2007). Luxembourg.

Drugi simpozij Naravne nesreče v Sloveniji - Neodgovorna odgovornost. URL: http:// www.sos112.si/slo/download.php?id=11603 (Citirano 12. 10. 2011).

Đurović, B., Mikoš M., 2006. Ali smo ogroženi kadar tvegamo? Pojmi in izrazje teorije tveganj zaradi naravnih, geološko pogojenih nevarnosti. Geologija, 49/1, str. 151161. Ljubljana.

Frantar, P., Robič, M., 2009. Podori na območju slapa Čedca. Ujma, 23, str. 82-87. Ljubljana.

Gale Encyclopedia of public health. URL: http://www.answers.com/topic/acceptable-risk-geophysics (Citirano 15. 9. 2011).

Gams, I., 1955. Snežni plazovi v Sloveniji v zimah 1950-1954. Geografski zbornik, 3, str. 121-219. Ljubljana.

Gams, I., 1983. Naravne nesreče v Sloveniji v pregledu. V: Naravne nesreče v Sloveniji kot naša ogroženost. Ljubljana, str. 10-17.

Geografie. Duden Basiswissen Schule, 2. izpopolnjena izdaja. Berlin, Duden Schulbuchverlag, 416 str.

Geografski terminološki slovar. 2005. Ljubljana, Založba ZRC, 451 str.

Grad, A., Škerlj, R., Vitorovič, N., 1998. Veliki angleško-slovenski slovar. Ljubljana, DZS, 1377 str.

Jeraj, J., 2010. Urbanistično načrtovanje prostora $v$ luči varstva pred naravnimi in drugimi nesrečami. V: Od razumevanja do upravljanja. Ljubljana, str. 221-233.

Kienholz, H., Zeilstra, P., Hollenstein, K., 1998. Begriffsdefinitionen Naturgefahren. Bern, Bundesamt für Umwelt, Wald und Landschaft (BUWAL), 74 str.

Klopčič, M., Poljanec, A., Bončina, A., 2010. Pojasnjevanje in modeliranje vetrolomov v gozdovih Julijskih Alp. V: Od razumevanja do upravljanja. Ljubljana, str. 59-64. 
Komac, B., Natek, K., Zorn, M., 2008. Geografski vidiki poplav v Sloveniji. Ljubljana, Založba ZRC, 180 str.

Komac, B., Zorn, M., Pavšek, M., 2010. Naravne nesreče - družbeni problem? V: Od razumevanja do upravljanja. Ljubljana, str. 9-18.

Kozelj, D., Kozelj, K., Steinman, F., Gosar, L., 2008. Poplavna ogroženost in posledice dogodkov preostalega tveganja. Ujma, 22, str. 145-151. Ljubljana.

Kraigher, A., Pahor, L., 2002. Nalezljive bolezni. V: Nesreče in varstvo pred njimi. Ljubljana, str. 351-359.

Lapajne, J., 1987. Strokovna beseda. Ujma, 1, str. 94. Ljubljana.

Leser, H., Haas, H.-D., Mosimann, T., Paesler, R., 1995. Diercke Wörterbuch der Allgemeinen Geographie, zv. 1 in 2. Braunschweig, Westermann, 422 in 421 str.

Lutman, M., Zupančič, P., Šket Motnikar, B., 2010. Dinamične lastnosti in potresna odpornost stavb v mestni občini Ljubljana. V: Od razumevanja do upravljanja. Ljubljana, str. 95-104.

Mikoš, M., 2010. Kako zmanjšati poplavne škode v Sloveniji? V: Od razumevanja do upravljanja. Ljubljana, str. 255-262.

Natek, K., 2002. Ogroženost zaradi naravnih procesov kot strukturni element slovenskih pokrajin. Dela, 18, str. 61-74. Ljubljana.

Natek, K., 2007. Geografske dimenzije naravnih nesreč in varstva pred njimi. Dela, 28, str. 147-164. Ljubljana.

Natek, K., 2011. Geografija naravnih nesreč. Študijsko gradivo za predmet Geografija naravnih nesreč. Ljubljana, Filozofska fakulteta, Oddelek za geografijo,190 str.

Navodilo o vsebini in metodologiji izdelave strokovnih podlag in prostorskih sestavin planskih aktov občin. 1985. Uradni list SRS, 20 (15. 6. 1985). Ljubljana.

Nova beseda. Inštitut za slovenski jezik Frana Ramovša ZRC SAZU. URL: http://bos. zrc-sazu.si/s_beseda.html (Citirano 13. 9. 2011).

Oxford English Dictionary Online. URL: http://www.oed.com.nukweb.nuk.uni-lj.si/viewdictionaryentry/Entry/53561 (Citirano 20. 9. 2011).

Plut, D., 2004. Geografske metode proučevanja degradacije okolja. Ljubljana, Oddelek za geografijo, Filozofska fakulteta, 188 str.

Polič, M., 2010. Od zaznavanja nevarnosti do kriznega upravljanja. V: Od razumevanja do upravljanja, Ljubljana, str. 139-148.

Radinja, D., 1983. Naravne nesreče v geografski luči. V: Prirodne nesreče v Jugoslaviji s posebnim ozirom na metodologijo geografskega proučevanja. Zbornik zveznega simpozija o metodologiji geografskega proučevanja naravnih nesreč. Ljubljana, str. 17-29.

Resolucija o strategiji nacionalne varnosti Republike Slovenije. 2010. Uradni list RS, 47 (2. 4. 2010). Ljubljana.

Slovar slovenskega knjižnega jezika. Ljubljana, Inštitut za slovenski jezik ZRC SAZU. URL: http://bos.zrc-sazu.si/sskj.html (Citirano 22. 10. 2011).

Smith, K., 2004. Environmental hazards. Assessing risk and reducing disaster. London, Routledge, 4. izdaja, 306 str.

Snoj, M., 1997. Slovenski etimološki slovar. Ljubljana, Založba Mladinska knjiga, 900 str. 
Stavbe po potresu. Kmetijske in rokodelske novice, 53, 17 (27. 04. 1895). URL: http:// www.dlib.si/?URN=URN:NBN:SI:DOC-QE8D8EFE (Citirano 5. 11. 2011).

Strategija prostorskega razvoja Slovenije. 2004. Ljubljana, Ministrstvo za okolje, prostor in energijo, 75 str. URL: http://www.mop.gov.si/fileadmin/mop.gov.si/pageuploads/ publikacije/drugo/sprs_slo.pdf(Citirano 16. 9. 2011).

Špes, M., Cigale, D., Lampič, B., Natek, K., Plut, D., Smrekar, A., 2002. Študija ranljivosti okolja (metodologija in aplikacija). Geographica Slovenica, 35, 1-2, str. 1-150. Ljubljana.

Tomaževič, M., 2002. Varstvo pred potresi. V: Nesreče in varstvo pred njimi. Ljubljana, str. 504-511.

Varnes, D. J., 1984. Landslide hazard zonation: a review of principles and practice. Commission of landslides of the IAEG, UNESCO. Paris, 63 str.

White, G. F. (ur.), 1974. Natural hazards: local, national, global. New York, Oxford University Press, 288 str.

Whittow, J. B., 2000. Dictionary of physical geography. London, Penguin, 590 str.

Wisner, B., Blaikie, P., Cannon, T., Davis, I., 2004. At risk. Natural hazards, people's vulnerability and disasters, 2. izdaja. London, Routledge, 471 str.

Zakon o varstvu okolja. 1993. Uradni list RS, 32 (17. 6. 1993). Ljubljana.

Zakon o varstvu okolja. 2004. Uradni list RS, 41 (22. 4. 2004). Ljubljana.

Zakon o varstvu pred naravnimi in drugimi nesrečami. 2006. Uradni list RS, 51 (18. 5. 2006). Ljubljana.

\section{BASICTERMS IN GEOGRAPHY OF NATURAL HAZARDS}

\section{Summary}

Natural disasters are extremely complex geographical features, an important component of the complex, two-way interactions between natural and social processes in the environment/space/landscape. These relationships affect the society in very different ways and at different levels, from individual to global but, the perception of these interactions at the level of individual, particular social group or society in general is very diverse and highly subjective. This is also reflected in the terms which try to define these relationships, since the complexity of natural disasters and society's response make very difficult to get to the standardized use of the basic scientific terminology. The key terms have not only a semantic dimension, but also mirror the key scientific paradigms and methodology of particular science. And because the natural disasters are a highly interdisciplinary field of research, both of natural and social sciences and, of course, geography, the problem of communication at the level of the basic terms is even worse.

One of basic paradigms in geography of natural disasters is the statement that natural disasters are an integral part of the environment/landscape/space and a specific segment of the complex relationships between man/society and nature. Almost all the basic terms presented in this paper relate to people/society, or his relationship to nature, in nature there are only certain processes, phenomena, circumstances, situations, 
opportunities, which could lead to a final event with negative impact on humans/society (this is a natural disaster), or not.

The presence of such hazards in the environment/landscape/space and their definite perception and understanding can be considered as an immanent threat to individuals, particular social groups or whole society. There is no way to avoid completely these threats (but we can elegantly negate them) and, therefore, our presence in the environment/ landscape/space, more or less fraught with hazards, is always associated with the risk to be exposed to some negative consequences of natural processes. Despite the enormous extent of some natural disasters (e.g. earthquakes, tsunamis), we are not completely helpless, since the anticipated negative effects can be largely mitigated by reducing our vulnerability (e.g. earthquake-resistant construction), or by adapting to existing natural conditions and limitations, e.g. by avoiding hazardous areas and, in general, by thoughtful and sustainable management of space and other natural resources.

Neither an individual nor the society as a whole will never fully succeed to 'clean' the environment from all the hazards and threats. Therefore, we need to provide in advance the proper conditions for successful coping with negative effects of natural disasters and adjust to 'unfavorable' natural conditions to achieve the highest possible level of resilience.

(Translated by the author) 